\title{
Article \\ The Impact of Graphite Oxide Nanocomposites on the Antibacterial Activity of Serum
}

\author{
Katarzyna Dorota Morka ${ }^{1, *}{ }^{(}$, Maciej Wernecki ${ }^{2}{ }^{(0}$, Anna Kędziora ${ }^{2}{ }^{(0}$, Marta Książczyk $^{2}$, Bartłomiej Dudek ${ }^{2}$,

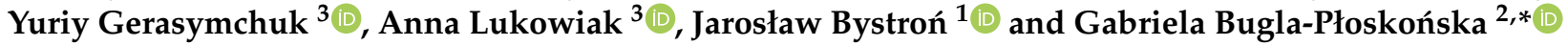 \\ 1 Department of Food Hygiene and Consumer Health Protection, Faculty of Veterinary Medicine, \\ University of Environmental and Life Sciences, C. K. Norwida 31, 50-375 Wrocław, Poland; \\ jaroslaw.bystron@upwr.edu.pl \\ 2 Department of Microbiology, Faculty of Biological Sciences, University of Wroclaw, \\ S. Przybyszewskiego 63/77, 51-148 Wroclaw, Poland; maciej.wernecki@uwr.edu.pl (M.W.); \\ anna.kedziora@uwr.edu.pl (A.K.); marta.ksiazczyk@uwr.edu.pl (M.K.); bartlomiej.dudek@uwr.edu.pl (B.D.) \\ 3 Institute of Low Temperature and Structure Research, Polish Academy of Sciences, ul. Okolna 2, \\ 50-422 Wrocław, Poland; y.gerasymchuk@intibs.pl (Y.G.); a.lukowiak@intibs.pl (A.L.) \\ * Correspondence: katarzyna.morka@upwr.edu.pl (K.D.M.); gabriela.bugla-ploskonska@uwr.edu.pl (G.B.-P.)
}

\section{check for} updates

Citation: Morka, K.D.; Wernecki, M.; Kẹdziora, A.; Książczyk, M.; Dudek,

B.; Gerasymchuk, Y.; Lukowiak, A.; Bystroń, J.; Bugla-Płoskońska, G. The Impact of Graphite Oxide Nanocomposites on the Antibacterial Activity of Serum. Int. J. Mol. Sci. 2021, 22, 7386. https:// doi.org/10.3390/ijms22147386

Academic Editor: Tanneke Den Blaauwen

Received: 6 May 2021

Accepted: 6 July 2021

Published: 9 July 2021

Publisher's Note: MDPI stays neutral with regard to jurisdictional claims in published maps and institutional affiliations.

Copyright: (c) 2021 by the authors. Licensee MDPI, Basel, Switzerland. This article is an open access article distributed under the terms and conditions of the Creative Commons Attribution (CC BY) license (https:// creativecommons.org/licenses/by/ $4.0 /)$
Abstract: Nanoparticles can interact with the complement system and modulate the inflammatory response. The effect of these interactions on the complement activity strongly depends on physicochemical properties of nanoparticles. The interactions of silver nanoparticles with serum proteins (particularly with the complement system components) have the potential to significantly affect the antibacterial activity of serum, with serious implications for human health. The aim of the study was to assess the influence of graphite oxide (GO) nanocomposites (GO, GO-PcZr $(\mathrm{Lys})_{2}-\mathrm{Ag}$, GO-Ag, GO-PcZr(Lys) $)_{2}$ ) on the antibacterial activity of normal human serum (NHS), serum activity against bacteria isolated from alveoli treated with nanocomposites, and nanocomposite sensitivity of bacteria exposed to serum in vitro (using normal human serum). Additionally, the in vivo cytotoxic effect of the GO compounds was determined with application of a Galleria mellonella larvae model. GO-PcZr(Lys) $)_{2}$, without IR irradiation enhance the antimicrobial efficacy of the human serum. IR irradiation enhances bactericidal activity of serum in the case of the GO-PcZr(Lys) $)_{2}-\mathrm{Ag}$ sample. Bacteria exposed to nanocomposites become more sensitive to the action of serum. Bacteria exposed to serum become more sensitive to the GO-Ag sample. None of the tested GO nanocomposites displayed a cytotoxicity towards larvae.

Keywords: GO nanocomposites; photoactivity; bactericidal action of serum; E. coli

\section{Introduction}

Recently, there was increasing research on the interactions of graphite oxide (GO) as well as various graphene products obtained from graphite oxide with biological objects [1]. Various mechanisms of the influence of these materials on living cells, both eukaryotic and prokaryotic, are discussed. Materials based on graphene are also tested in terms of their application in diagnostics [2,3], where both carbon materials, for example, quantum dots [4,5], and composite systems are developed [6]. One of the potential directions of application of these materials is their use in photodynamic therapies including antibacterial activity, which is particularly interesting as an alternative to antibiotic therapy. Graphene and graphene products have more interesting and favorable physicochemical properties compared to that of graphite oxide, but their disadvantage is that they do not contain active groups, which can be chemically modified, and their introduction into the graphene structure is very complicated and is associated with disturbance of the native structure and loss of their properties. In terms of chemical modification, graphite oxide is more interesting because it has many active groups containing oxygen on its surface which can be chemically modified without significantly disturbing its structure. 
As a component of composite materials, especially photoactive, graphite oxide plays a triple role. On the one hand, it can act as an antenna for photons, with the subsequent transfer of energy obtained from the light to photosensitizer particles or luminescent nanoparticles, and on the other hand, it allows for enhancement of the antibacterial effect of silver (both in ionic and nanoparticle forms) [7-11]. A photosensitizer-a complex of zirconium (IV) phthalocyanine-is herein proposed as a photoactive component bonded to $\mathrm{GO}$ flakes. Its presence ensures generation of singlet oxygen molecules after near infrared light exposure, which may cause death of bacterial cells. To strengthen the bactericidal effect, silver nanoparticles can be introduced to the system as well.

More than 700 prokaryotic species in the human oral cavity, belonging to 13 separate phyla, are noted in the literature. Due to the specific environmental conditions, the species diversity within the infected root canal is usually limited, up to 10-30 species per canal [12]. Aerobic (such as streptococci, staphylococci, enterococci, Enterobacteriaceae), anaerobic (such as Fusobacterium, Prevotella and Porphyromonas spp.) and microaerophiles (such as Lactobacillus, Actinomyces, and Propionibacteria spp.) are the bacteria most frequently isolated from the root canal [13].

Besides the previous studies, where the antibacterial activity of GO nanocomposites was determined, we decided to check the impact of reduced GO (rGO) nanocomposites on the antibacterial efficacy of serum after recognition that nanomaterials introduced into the body tend to influence the complement system and can interact with different components of the serum, including immunologically significant complement proteins $[14,15]$. A proteomic study [16] demonstrated that some serum proteins can bind to nanoparticles. The total amount and type of proteins bound to nanoparticles depend on the physicochemical properties of the nanoparticles. However, the implications of the binding of serum proteins to silver nanoparticles regarding the complement activation and immune response against bacteria were not fully investigated.

Serum contains crucial elements of immunity as part of the host defense system, such as immunoglobulin or the complement system. The complement system (35-40 proteins in the blood plasma) plays a fundamental role in mediating and enhancing humoral immunity. Under normal conditions, activation of any of the three complement pathways-the classical, alternative, or lectin-results in formation of the membrane attack complex (MAC). When this activation occurs in the presence of antigens (e.g., outer membrane structures of bacteria), the generated MAC may form transmembrane pores in the phospholipid bilayer of the targeted bacteria cell, causing complement-mediated cytolysis [17].

Because mammalian models of infection have numerous disadvantages such as high cost, ethical constraints, and specialized equipment and laboratories, a promising and reliable alternative method to investigate the in vivo activity of antimicrobial agents is invertebrate models, such as Galleria mellonella (greater wax moth) larvae $[18,19]$. The larvae were widely used as an infection model to study a large range of pathogens [20-24]. The reason why G. mellonella larvae have application in in vivo pathogenicity, toxicity, and antimicrobial activity testing is the high degree of similarity of the larval immune system to the innate immune system of mammals, including humans [23]. Previous studies showed a strong positive correlation of virulence of different pathogens between mouse infection systems and G. mellonella [20-24]. In the present study we applied tested nanocomposites to G. mellonella larvae as an alternative model to examine the cytotoxicity of designed nanocomposites and predict their suitability for clinical use in humans. The aim of the study was to assess the influence of GO nanocomposites on the antibacterial activity of normal human serum (NHS), serum activity against bacteria treated with nanocomposites, and nanocomposite sensitivity of bacteria exposed to serum in vitro and in vivo (using the G. mellonella model). The model of research using GO with serum and G. mellonella larva interaction was not previously presented in the literature. The following materials were used for testing: GO, GO with silver nanoparticles (GO-Ag), GO with attached molecules of bis(lysinato)zirconium(IV) phthalocyanine complex (GO-PcZr $\left.(\mathrm{Lys})_{2}\right)$, and the latter with silver nanoparticles (GO-PcZr(Lys) $\left.{ }_{2}-\mathrm{Ag}\right)$. 


\section{Results}

2.1. Survival of E. coli 6.2E in NHS, iNHS (Inactivated Serum) and Nanocomposites (GO, GO-PcZr(Lys) $\left.{ }_{2}-A g, G O-A g, G O-P c Z r(L y s)_{2}\right)$ with and without IR Irradiation

First, the efficacy of $25 \%$ NHS against $E$. coli 6.2E isolated from alveoli was determined; this constituted a control for further experiments. The results showed that NHS shows bactericidal activity against the tested E. coli 6.2E strain during $60 \mathrm{~min}$. E. coli 6.2E maintained the ability to survive in $25 \%$ NHS during the tested time (at T60, bacterial CFU / mL was equal to $1.39 \times 10^{6}$ (as illustrated in Table A1), which is $22 \%$ of the CFU/mL at T0, when the bacterial survival rate is $100 \%, p=0.0070$ ), while in iNHS the strain multiplied (142\% survival, $p>0.05$, Figure 1A). The addition of GO-PcZr(Lys) $)_{2}-\mathrm{Ag}$ and GO-PcZr(Lys) to the environment of NHS and bacterial cells did not significantly enhanced the decrease in bacterial count compared to NHS $(19 \%(p=0.0050)$ and $13 \%(p=0.0091)$ survival, respectively), while in iNHS and GO-PcZr(Lys) $)_{2}-\mathrm{Ag}$ the strain $\mathrm{CFU} / \mathrm{mL}$ decreased insignificantly after $60 \mathrm{~min}\left(\mathrm{CFU} / \mathrm{mL}\right.$ at T0 equal to $5.82 \times 10^{6}$ decreased to $\left.4.23 \times 10^{6}\right)$. One hour is not enough for nanocomposites GO-PcZr(Lys) ${ }_{2}-\mathrm{Ag}$ and GO-PcZr(Lys) ${ }_{2}$ simultaneously added to NHS and E. coli 6.2.E to block or stimulate the complement activity (as illustrated in Figure 1C).

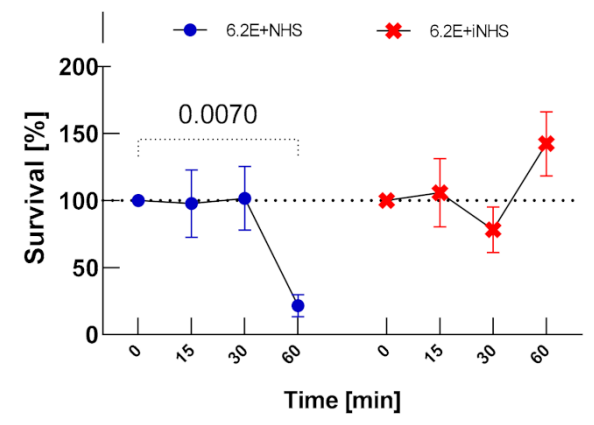

(A)

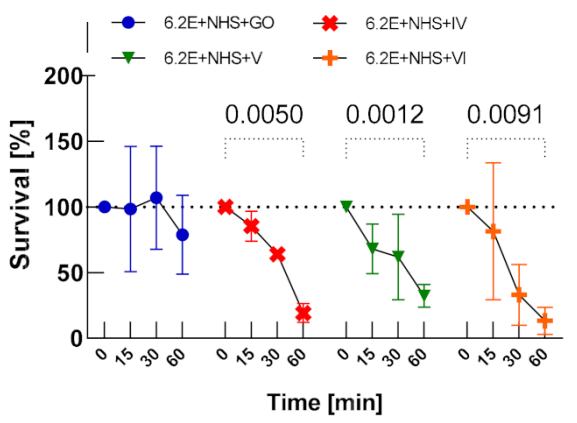

(C)

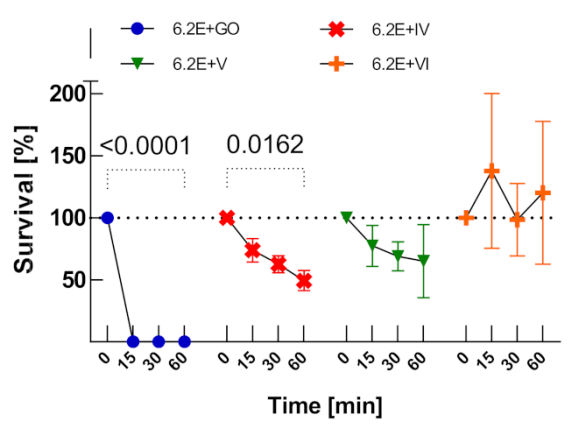

(B)

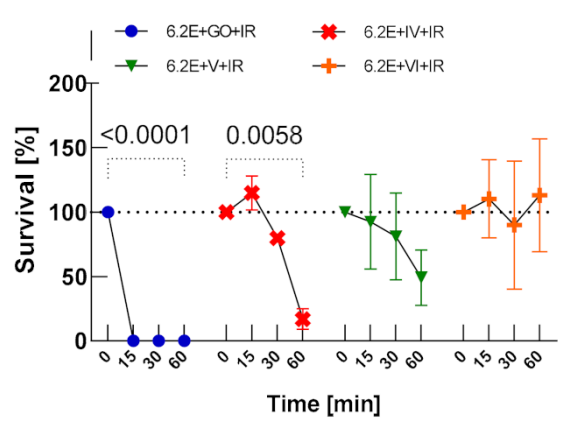

(D)

Figure 1. Bacterial survival in: NHS and iNHS (A), nanocomposites GO, IV: GO-PcZr(Lys) ${ }_{2}-\mathrm{Ag}$, V: GO-Ag, VI: GO-PcZr(Lys) 2 without IR irradiation (B), nanocomposites GO, IV: GO-PcZr(Lys) $)_{2}-\mathrm{Ag}$, V: GO-Ag, VI: GO-PcZr(Lys) 2 with IR irradiation (D) and mixed NHS with nanocomposites (C). Graphs represent the percentage of live bacteria in the sample relative to the average number at time zero. Standard deviation values are presented with error bars, Dunnett's test $p$-values for within group T0-T60 pairs are shown above graph when equal or lower than 0.05. Mixed-model ANOVA results are presented in Table A3 in Appendix D. Corresponding results obtained for strain E. coli J53 are presented in Figure A5 in Appendix C.

Incubation of E. coli 6.2E with GO-PcZr(Lys) $)_{2}-\mathrm{Ag}(p=0.0162), \mathrm{GO}-\mathrm{Ag}(p>0.05)$, and $\mathrm{GO}(p<0.0001)$ showed reduction of the number of bacteria (as illustrated in Figure 1B). The bactericidal effect was enhanced by light exposure (broadband light in the red and nearinfrared region, IR) only in the case of nanocomposite GO-PcZr $(\mathrm{Lys})_{2}-\mathrm{Ag}$ (as illustrated in Figure 1D, $p=0.0058$ ). 
2.2. The Influence of Nanocomposites (GO, GO-PcZr(Lys) $\left.)_{2}-A g, G O-A g, G O-P c Z r(L y s)_{2}\right)$ on the Bacterial Serum Survival

The nanocomposites influenced the bacterial serum survival. There was a slight decrease in CFU / mL of E. coli 6.2E in GO-PcZr(Lys) $)_{2}$-Ag-exposed NHS from $6.62 \times 10^{6}$ at T0 to $6.5 \times 10^{6}$ at T60, which is $98 \%$ of the T0 value $(p>0.05$, as illustrated in Figure $2 \mathrm{~A})$. Similarly, this strain displayed high-level resistance to GO-treated serum (150\% survival, $p>0.05$ ) (as illustrated in Figure 2A). In contrast, there was $22 \%$ survival of bacteria in the active NHS (as illustrated in Figure 1A) and survival of $19 \%$ of bacteria after simultaneous mixing with NHS and GO-PcZr(Lys) ${ }_{2}-\mathrm{Ag}$ (as illustrated in Figure 1C). However, the GO-Ag and GO-PcZr(Lys) ${ }_{2}$ nanocomposites led to a decrease of bacterial survival in serum $(23 \%$ $(p>0.05)$ and $27 \%(p=0.0416)$ survival, respectively, as illustrated in Figure $2 \mathrm{~A})$ and GO-Ag maintained its ability to reduce bacteria at a similar level as observed in GO-Agtreated iNHS (survival decreased to $37 \%, p=0.0304$, as illustrated in Figure 2B). The bactericidal effect was mainly influenced by the serum, and the GO-Ag nanocomposite played a supporting role in this phenomenon. On the other hand, a slight decrease in $\mathrm{CFU} / \mathrm{mL}$ from T0 $4.59 \times 10^{6}$ to $3.71 \times 10^{6}$ at T60 was recorded for E. coli 6.2E in GO$\mathrm{PcZr}(\mathrm{Lys})_{2}$-Ag-treated inactivated serum ( $88 \%$ survival, $p>0.05$, as illustrated in Figure 2B). A similar decrease was also observed for GO-treated iNHS; the strain exhibited $74 \%$ survival $p>0.05$.

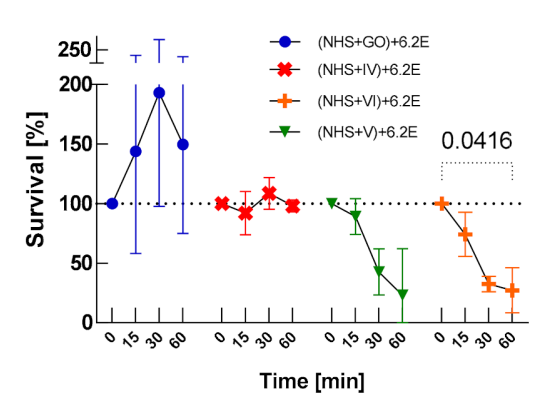

(A)

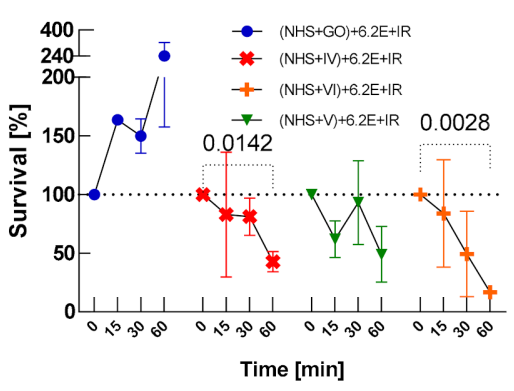

(C)

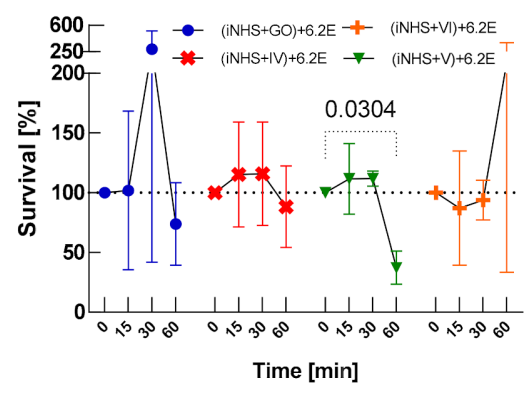

(B)

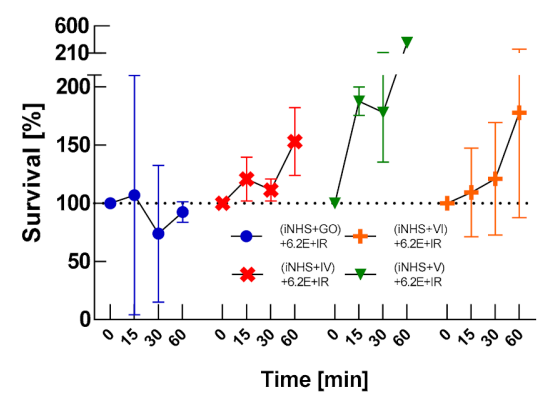

(D)

Figure 2. Bactericidal effectiveness of NHS exposed to nanocomposites (GO, IV: GO-PcZr(Lys) ${ }_{2}-\mathrm{Ag}$, V: GO-Ag, VI: GO-PcZr(Lys) 2 ) before (A) and after IR irradiation (C), the control test in iNHS (B,D). Graphs represent percentage of live bacteria in sample relative to average number at time zero. Standard deviation values are presented with error bars, Dunnett's test $p$-values for within group T0-T60 pairs are shown above graph when equal or lower than 0.05. Mixed-model ANOVA results are presented in Table A3. Corresponding results obtained for strain E. coli J53 are presented in Figure A6.

Significant enhancement $(p=0.0117$, between T60 survival values from tests $(\mathrm{NHS}+\mathrm{IV})+6.2 \mathrm{E}$ withut IR vs. (NHS+IV)+6.2E+IR) of the bactericidal effect was observed in GO-PcZr(Lys) ${ }_{2}$-Ag-treated NHS, subsequently IR-exposed (decrease of CFU $/ \mathrm{mL}$ from $4.37 \times 10^{6}$ to $1.88 \times 10^{6}$ after $60 \mathrm{~min}$ of incubation) (as illustrated in Figure 2C). Thus, the previously observed insignificant reduced bactericidal ability shown by GO-PcZr(Lys) ${ }_{2}-\mathrm{Ag}$ - 
treated NHS (as illustrated in Figure 2A) was intensified by IR light $(p=0.0142)$. However, in the case of iNHS exposed to GO-PcZr( $\mathrm{Lys})_{2}-\mathrm{Ag}$ nanocomposite ((iNHS + GO-PcZr $(\mathrm{Lys})_{2^{-}}$ $\mathrm{Ag})+$ E. coli $6.2 \mathrm{E}+\mathrm{IR})$ the IR did not maintain the GO-PcZr(Lys) $)_{2}-\mathrm{Ag}$-mediated ability to reduce the number of bacteria as was the case in the experiment without IR irradiation (as illustrated in Figure 2B). The reactions without GO-PcZr(Lys) ${ }_{2}-\mathrm{Ag}$ nanocomposite excluded the possibility that IR light induced the local heating of the serum (data not shown). The role of IR irradiation in reducing the number of bacteria was not clearly observed in GO, GO-Ag, and GO-PcZr(Lys) $)_{2}$-exposed NHS (240\%, 50\% and $17 \%$ survival, respectively, as illustrated in Figure 2C), because without IR the strain displayed similar susceptibility (150\%, 23\% and $27 \%$ after 60 min of incubation, as illustrated in Figure 2A). The summarized clustering analysis is presented in Figure 3.

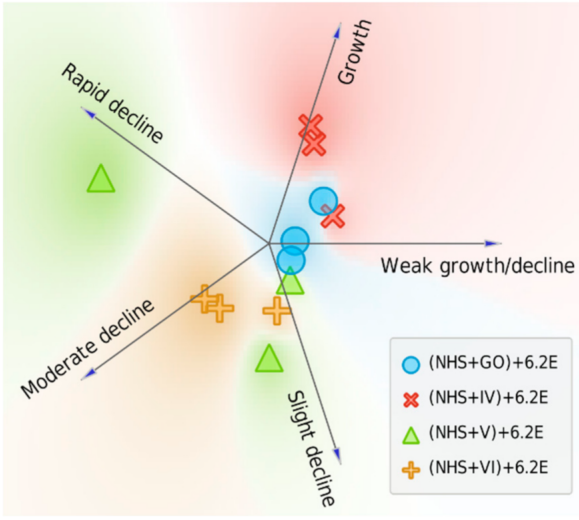

(A)

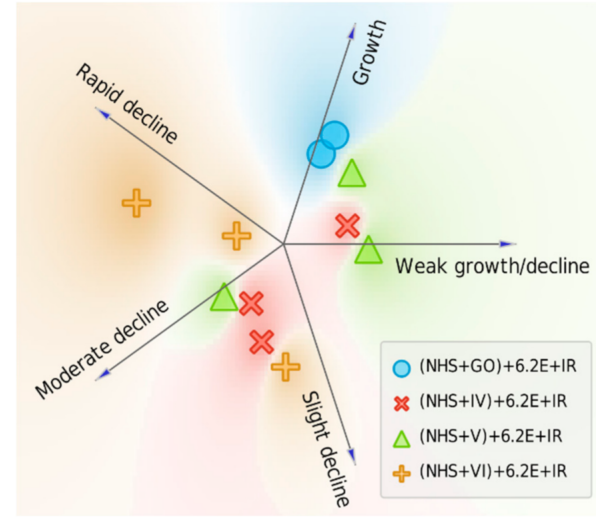

(B)

Figure 3. Survival of E. coli 6.2E was altered when bacteria were exposed to IR irradiated NHS with nanocomposites. Each replicate is represented with an individual sign and placed according to the probability of belonging to a particular cluster (numerical data shown in Table A3). Survival was decreased with the nanocomposite GO-PcZr(Lys) $)_{2}-\mathrm{Ag}$ (note the shift of the red Xs from cluster 'Growth' (A) closer to cluster 'Moderate decline' (B)).

\subsection{Serum Activity against Bacteria Treated with Nanocomposites and Nanocomposite Sensitivity of Bacteria Exposed to Serum}

The most bactericidal effect and also the fastest reduction rate of the bacterial CFU $/ \mathrm{mL}$ were observed after nanocomposite treatment, which may suggest that the nanocomposites make bacteria more susceptible to the complement action. Only $12 \%(p=0.0036), 1 \%$ $(p<0.0001)$, and $1 \%(p=0.0143)$ of bacteria exposed to GO-PcZr(Lys $)_{2}-\mathrm{Ag}, \mathrm{GO}-\mathrm{Ag}$, and GO$\mathrm{PcZr}(\mathrm{Lys})_{2}$ nanocomposites, respectively, survived the human serum activity. E. coli 6.2E showed high susceptibility to GO action with a survival rate of $0 \%$ after 30 -min incubation before the serum treatment (as illustrated in Figure 4A).

Serum survival of nanocomposites-treated E. coli 6.2E was many times lower compared to bacteria not exposed to GO, GO-PcZr(Lys) $)_{2}-\mathrm{Ag}$, GO-Ag, and GO-PcZr(Lys) $)_{2}$ action, which may suggest that the interaction of bacteria with nanocomposites facilitates the NHS activity (as illustrated in Figures $1 \mathrm{C}$ and $4 \mathrm{~A}$ ). On the other hand, the changes caused by GO-PcZr(Lys) $)_{2}-\mathrm{Ag}$ and GO-PcZr(Lys) ${ }_{2}$ nanocomposites were not so severe, so bacterial cells were able to multiply again in iNHS. GO-PcZr $(\mathrm{Lys})_{2}-\mathrm{Ag}$ and GO-PcZr $(\mathrm{Lys})_{2}$-exposed E. coli $6.2 \mathrm{E}$ exhibited $127 \%$ and $115 \%(p>0.05)$ survival in iNHS, respectively, after 60 -min incubation (as illustrated in Figure 4B). The GO-Ag-treated strain displayed a low level of survival in iNHS ( $1 \%$ after 60 min incubation, $p=0.0001$ ), while GO exposure led to total death of bacteria. The summarized clustering analysis is presented in Figure 5. 


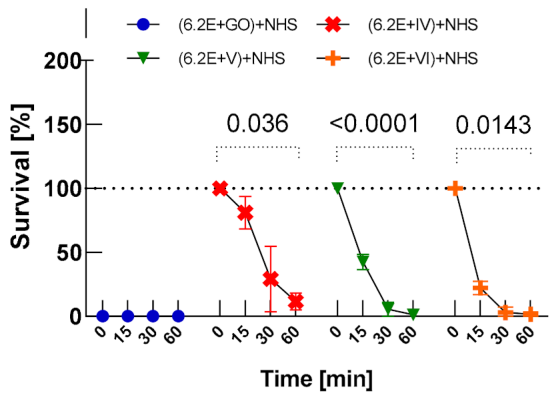

(A)

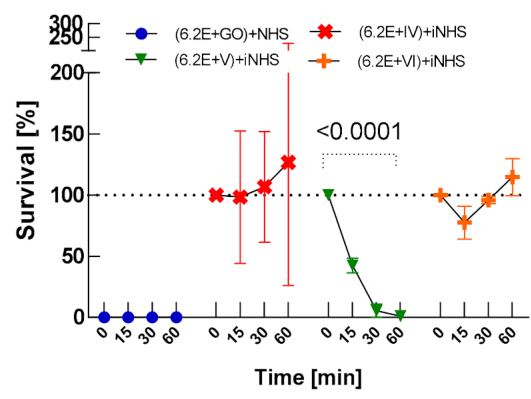

(B)

Figure 4. Serum sensitivity of E. coli 6.2E exposed to nanocomposites (GO, IV: GO-PcZr(Lys) ${ }_{2}-\mathrm{Ag}$, V: GO-Ag, VI: GO-PcZr(Lys) 2 ) (A) and control test in iNHS (B). Graphs represent percentage of live bacteria in sample relative to average number at time zero. Standard deviation values are presented with error bars, Dunnett's test $p$-values for within group T0-T60 pairs are shown above graph when equal or lower than 0.05. Mixed-model ANOVA results are presented in Table A3. Corresponding results obtained for strain E. coli $J 53$ are presented in Figure A7.

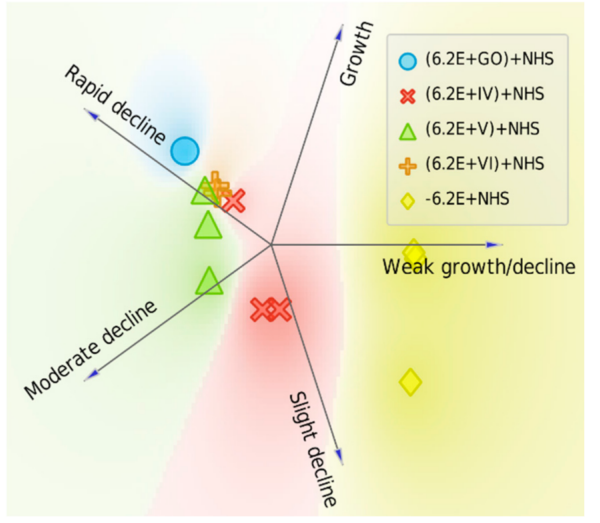

(A)

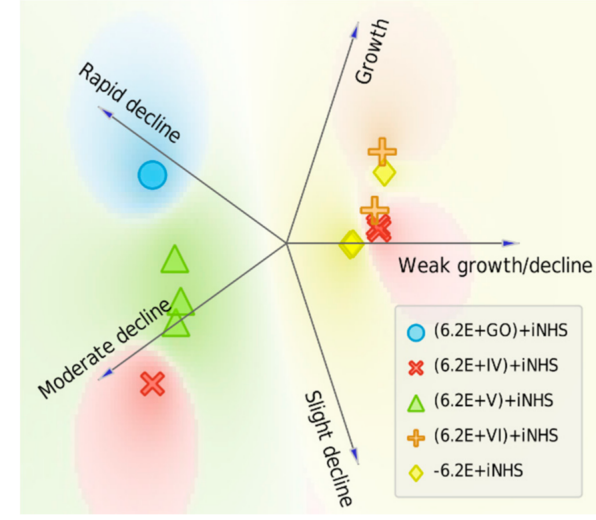

(B)

Figure 5. Survival of E. coli 6.2E was reduced when bacteria were exposed to nanocomposites followed by NHS treatment. Each replicate is represented with an individual sign and placed according to the probability of belonging to a particular cluster (numerical data shown in Table A3). Effect is notable with nanocomposites IV: GO-PcZr(Lys) $)_{2}-\mathrm{Ag}$, V: GO-Ag, VI: GO-PcZr(Lys) (shift to the 'decline' clusters when compared to baseline 6.2E + NHS experiment, (A). Effect of nanocompositeinduced sensitization is maintained in iNHS only for nanocomposite V: GO-Ag, for which all replicates are clustered as 'moderate decline' (B).

Treatment of bacteria with NHS for 30 min prior to the action of nanocomposites did not lead to the death of the bacterial population. The strain exhibited $68 \%, 46 \%$, and $93 \%$ survival for GO-PcZr(Lys) $)_{2}-\mathrm{Ag}$, GO-PcZr(Lys) $)_{2}$, and GO, respectively, after 60 min of the experiment $(p>0.05)$. Only GO-Ag nanocomposite statistically significantly reduced the survival of NHS-exposed bacteria to $1 \%(p<0.0001)$ (as illustrated in Figure 6A). 


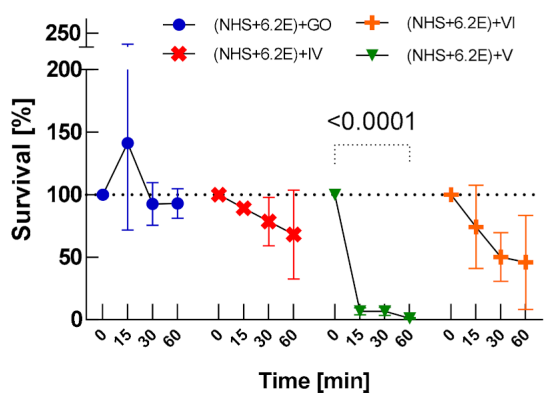

(A)

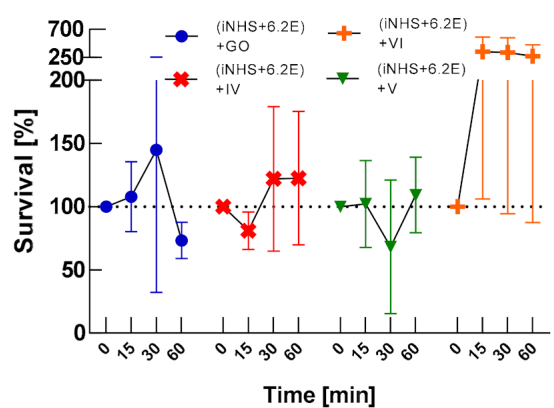

(B)

Figure 6. Sensitivity of E. coli 6.2E to nanocomposites (GO, IV: GO-PcZr(Lys) ${ }_{2}-\mathrm{Ag}$, V: GO-Ag, VI: GO-PcZr(Lys) $)_{2}$ ) after exposure to serum (A) and control test in iNHS (B). Graphs represent percentage of live bacteria in sample relative to the average number at time zero. Standard deviation values are presented with error bars, Dunnett's test $p$-values for within group T0-T60 pairs are shown above graph when equal or lower than 0.05. Mixed-model ANOVA results are presented in Table A3. Corresponding results obtained for strain E. coli J53 are presented in Figure A8.

In contrast, there were $19 \%, 13 \%$, and $79 \%$ of CFU / $\mathrm{mL}$ of surviving bacteria when no NHS treatment was applied to bacteria (as illustrated in Figure 1C), which may suggest that such an interaction of bacteria with NHS blocks the action of the compound GOPcZr(Lys) $)_{2}-\mathrm{Ag}$, GO-PcZr(Lys) 2 and GO on bacteria.

Only GO reduced the bacterial population exposed to inactivated NHS by up to $73 \%$ (as illustrated in Figure 6B, $p>0.05$ ). This iNHS-exposed strain also exhibited 109\%, $122 \%$, and $268 \%$ survival after 60 min of incubation in GO-PcZr(Lys) ${ }_{2}, \mathrm{GO}-\mathrm{PcZr}(\mathrm{Lys})_{2}-\mathrm{Ag}$, and GO-Ag nanocomposites, respectively $(p>0.05)$ (as illustrated in Figure 6B). The summarized clustering analysis is presented in Figure 7.

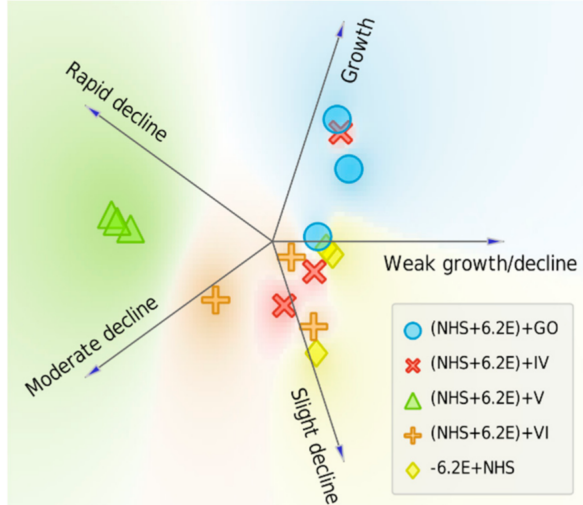

(A)

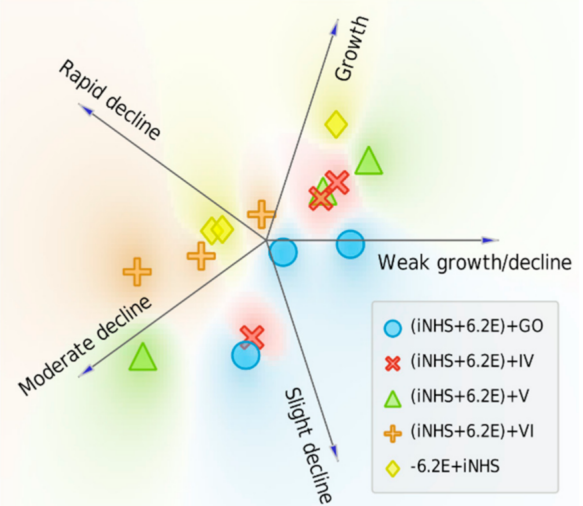

(B)

Figure 7. Survival of E. coli 6.2E was changed when bacteria were treated with nanocomposites exposed to NHS. Each experiment is represented with an individual sign and placed according to probability of belonging to a particular cluster (numerical data shown in Table A3). Bactericidal effect was enhanced in the experiment with nanocomposite V: GO-Ag, where NHS pretreatment caused a shift towards 'Moderate decline' and 'Rapid decline' clusters (A). The opposite effect was observed for GO, where contact with NHS reduced its effectiveness. When iNHS was applied, no nanocomposite maintained rapid bactericidal action (B).

\subsection{Galleria mellonella-In Vivo Cytotoxicity Tests}

In vivo cytotoxicity tests were conducted at least three times for each graphite nanocomposite. After separate application of graphite nanocomposites into the hemocoel of larvae $(n=10)$, the medium percentage survival of larvae was in the range of about $90-100 \%$ 
(as illustrated in Table 1). Nanocomposites in previously determined MIC concentrations exhibited no cytotoxic effect for G. mellonella larvae (as illustrated in Figure 8).

Table 1. Survival of G. mellonella larvae during $24 \mathrm{~h}$ after application of graphite nanocomposites in MIC concentration: GO-PcZr(Lys) $)_{2}-\mathrm{Ag} 64 \mu \mathrm{g} / \mathrm{mL}$; GO-Ag $512 \mu \mathrm{g} / \mathrm{mL}$; GO- PcZr(Lys) ${ }_{2}$ and rGO $4096 \mu \mathrm{g} / \mathrm{mL}$.

\begin{tabular}{ccccc}
\hline & \multicolumn{4}{c}{ Larvae Survival in 24 $\mathbf{h}$ after } \\
& \multicolumn{3}{c}{ Nanocomposite Administration } \\
& Rumber of Live Larvae $[n]$ (Percentage of Live Larvae [\%]) \\
\hline Nanocomposites & Run 1 & Run 2 & Run 3 & Medium \\
\hline GO-PcZr(Lys) $)_{2}-\mathrm{Ag}(\mathrm{IV})$ & $9(90 \%)$ & $10(100 \%)$ & $9(90 \%)$ & $9.3(93 \%)$ \\
GO-Ag (V) & $10(100 \%)$ & $10(100 \%)$ & $10(100 \%)$ & $10(100 \%)$ \\
GO-PcZr(Lys) $)_{2}(\mathrm{VI})$ & $9(90 \%)$ & $10(100 \%)$ & $10(100 \%)$ & $9.6(96 \%)$ \\
rGO & $8(100 \%)$ & $10(100 \%)$ & $9(100 \%)$ & $9(90 \%)$ \\
\hline
\end{tabular}

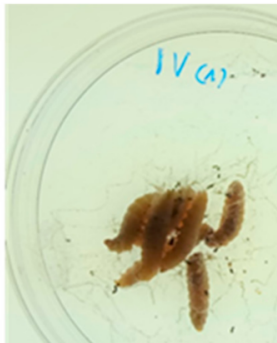

A.

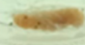

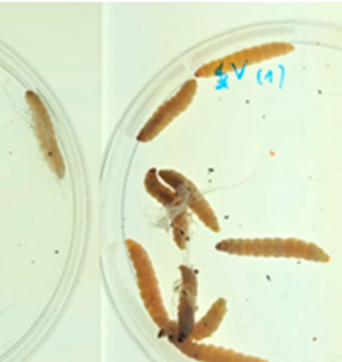

B.
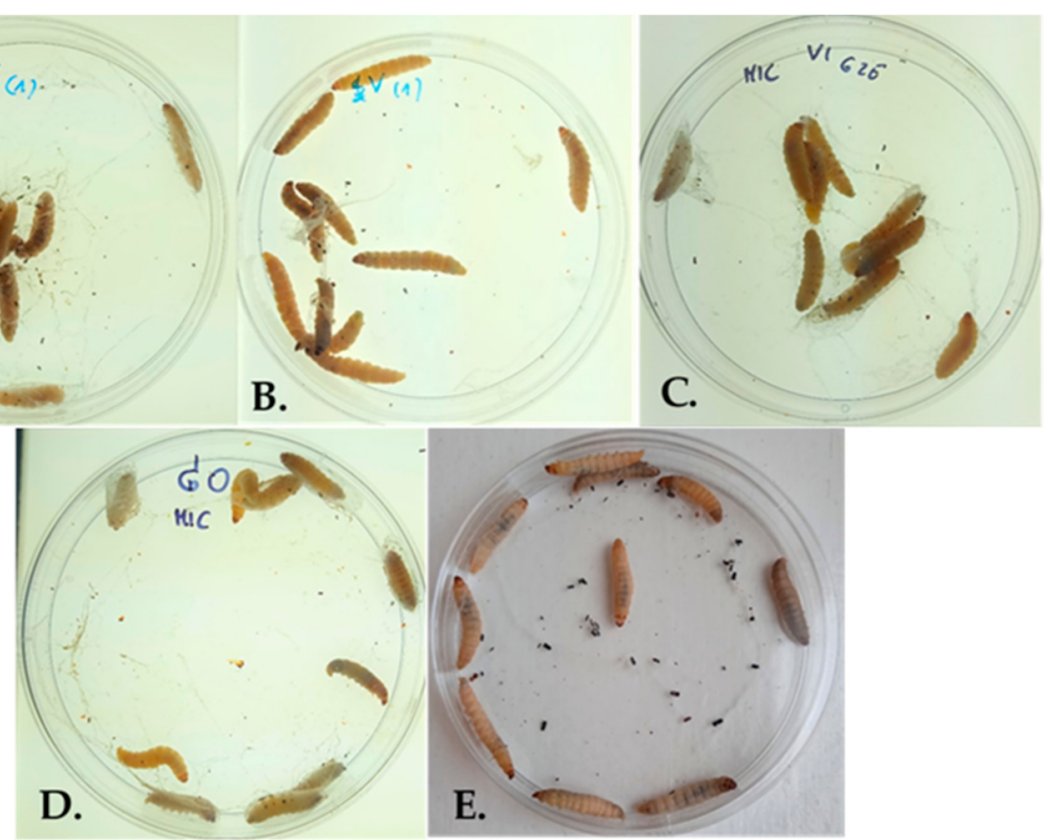

Figure 8. G. mellonella larvae after injection of following graphite nanocomposites in MIC concentration: GO-PcZr(Lys) $)_{2}-\mathrm{Ag}$ (A); GO-Ag (B); GO-PcZr(Lys) 2 (C); GO (D); PBS control-Larvae $(n=10)$ injected with sterile PBS buffer (E).

\section{Discussion}

The choice of phthalocyanines as photosensitizers in composite materials was dictated by the fact that, first of all, as a group of macrocyclic compounds, they were already used in traditional photodynamic therapy (e.g., for cancer treatment) as well as in antibacterial photodynamic therapy [25-27] due to high absorption coefficients and absorption and emission bands in the "biological window" range. The biological window is the range of the light spectrum in which it penetrates deeply (up to $2 \mathrm{~cm}$ ) into the tissues of a living organism without being absorbed by biological substances and corresponds to the wavelength range of $600-900 \mathrm{~nm}$. Moreover, the generation of reactive oxygen species under the influence of light from this range was proven for phthalocyanines, which is an additional advantage related to their action in photodynamic therapy. Phthalocyanine compounds might have an advantage over typical antiseptics (hypochlorite, chlorhexidine, or coumarins), which are unstable in the long term or toxic to the body when washed out by body fluids, and antibiotics, which also have low stability and at low concentrations lead to bacterial adaptation and formation of resistant strains rather than to the desired antiseptic effect $[28,29]$. 
Husain et al. [30] reported that a small fraction of nanomaterials can translocate from lungs to blood and can activate C3 protein (one crucial protein of the complement system). Long-term accumulation of nanoparticles can lead to chronic airway inflammation, where the complement system can be involved [31]. Keiser et al. [32] showed that in someone exposed to nano- $-\mathrm{TiO}_{2}$ and nano- $\mathrm{SiO}_{2}$ at concentrations up to $243 \mu \mathrm{g} / \mathrm{mL}$ for $48 \mathrm{~h}$, neither the gastrointestinal cells nor the immune system cells were significantly affected. However, when exposed to silver nanoparticles, several cell parameters were affected, but far less than by silver ions used as a control.

Hunag et al. [33] in 2016 described a study in which they investigated the blood biological effect of silver nanoparticles with two different surface coatings on serum immunity: polyvinyl pyrrolidone and polyvinyl pyrrolidone-citrate. They reported that those materials did not show any effect on complement activation at the concentration range from about 1 to $40 \mu \mathrm{g} / \mathrm{mL}$. Yu et al. [31] found C3 as a protein bound on glycopolymer-grafted nanoparticles, which can modulate and amplify the complement system. Sladowski [34] and Moghimi et al. [35] concluded that silver nanoparticles with different physicochemical properties are involved only in the alternative pathway of complement activation, and nanoparticles with size $35 \mathrm{~nm}$ are better activators of complement than $25 \mathrm{~nm}$ and $10 \mathrm{~nm}$. However, Fornaguera et al. [36] found no correlation between nanoparticle size and activation of the complement system.

There is a huge gap in the literature covering the influence of graphene nanocomposites on the nonspecific immunity and their antibacterial efficacy. Despite poor biosolubility and biocompatibility and induction of cell death, graphene oxide was considered as a promising vaccine carrier and adjuvant in activating cellular and humoral immunity [37]. Zhang et al. [38] confirmed the significant increase of host-immunity-related $\mathrm{CD} 8^{+} \mathrm{T}$ cells (cytotoxic T lymphocytes) and proinflammatory cytokines, including IFN- $\gamma$ and TNF- $\alpha$, after photo-activated antitumor activity with graphene quantum-dot-mediated photodynamic therapy. Cao et al. [37] stated that the surface modifications of graphene oxide and their functionalization are crucial for individual applications taking into consideration the biological interaction. The differences in interaction of graphite nanocomposites with human serum were noted by us. Final conclusions strongly depend on the physicochemical properties of nanomaterials. We found that pure GO or graphene oxide doped with silver and phthalocyanines complex (GO-PcZr(Lys) $)_{2}-\mathrm{Ag}$ ) had a completely different influence on serum compounds and their antibacterial efficacy than GO-PcZr(Lys $)_{2}$ or GO-Ag. The crucial points are the external factors such as IR irradiation, which we also observed, and it does not depend on the chemical composition of the sample. It is worth underlining that the obtained results also depend on the point of immunological response. The contact of an antigen (bacterial) with human serum occurs with the existence of other complement components. Antibacterial activity of human serum may decrease after contact with pure GO and GO-PcZr(Lys) $)_{2}-\mathrm{Ag}$ but increase after exposure to GO-PcZr(Lys $)_{2}$ or GO with silver nanoparticles (with $\mathrm{Ag}$ diameter about $10 \mathrm{~nm}$ ) added to these samples, enhancing antibacterial efficacy of graphite nanocompounds. As we previously noted, the response of bacterial cells to silver nanoparticles depends on the physicochemical properties of the nanoformulations (such as size, shape, charge, surface area, compounds, etc.) and individual features of bacterial strains (such as structural compounds and metabolism), and the incorporation of silver into industrial products should be considered to create a separate agent with a potentially different mode of antibacterial action [39].

Survival of E. coli 6.2E was tested in different environments, i.e., in $25 \% \mathrm{NHS}, 25 \%$ iNHS, nanocomposites (GO, GO-PcZr(Lys) $)_{2}-\mathrm{Ag}$, GO-Ag or GO-PcZr(Lys) $\left.{ }_{2}\right)$ with or without IR irradiation as a control being a reference for further reactions. The control experiment was also simultaneously mixed bacteria with nanocomposites and serum. These results showed that almost all (except for GO-PcZr(Lys) 2 and GO-Ag, $p>0.05$ ) of the mentioned environments had a reducing effect on the number of bacteria. E. coli $6.2 \mathrm{E}$ had $22 \%, 0 \%, 49 \%$, $65 \%$ and $120 \%$ survival in $25 \%$ NHS, GO, GO-PcZr(Lys) $)_{2}-\mathrm{Ag}$, GO-Ag, and GO-PcZr(Lys) ${ }_{2}$, respectively (as illustrated in Figure 1). This strain also showed 79\% $(p>0.05), 19 \%$ 
$(p=0.0050), 32 \%(p=0.0012)$, and $13 \%(p=0.0091)$ survival in simultaneously mixed NHS with GO, GO-PcZr(Lys) ${ }_{2}-\mathrm{Ag}$, GO-Ag, and GO-PcZr(Lys) $)_{2}$ nanocomposites, respectively. These results showed that one hour is not enough for nanocomposites GO-PcZr(Lys) ${ }_{2}-\mathrm{Ag}$ and GO-PcZr(Lys $)_{2}$ simultaneously added to NHS and E. coli 6.2.E to block or stimulate the complement activity (as illustrated in Figure 1C). Only GO-PcZr(Lys) ${ }_{2}-\mathrm{Ag}$ nanocomposite had an enhanced bactericidal effect after IR irradiation (as illustrated in Figure 1D, $p=0.0058$ ). Bacteria incubated in iNHS and the nanocomposite GO-Ag had similar survival (31\% in iNHS and GO-Ag, data not shown) compared to active serum (32\% in NHS and GO-Ag), which strongly suggests the significant role of the nanocomposite GO-Ag in the bactericidal effect (as illustrated in Figure 1C).

Further experiments included treatment for $30 \mathrm{~min}$ with a single component before mixing with the rest of them for $60 \mathrm{~min}$, and their aim was to verify whether the treatment of a single component had an impact on the bacterial sensitivity to nanocomposites or human serum, respectively. NHS exposure to GO-PcZr(Lys) $)_{2}-\mathrm{Ag}$ and GO, and GO-Ag without IR irradiation had no statistically significant impact on bactericidal action. However, the NHS treatment of GO-PcZr(Lys) ${ }_{2}$ nanocomposite resulted in the decrease of bacterial serum survival ( $27 \%$ survival, $p=0.0416$, as illustrated in Figure $2 \mathrm{~A}$ ). It showed that the nanocomponent GO-PcZr(Lys) $)_{2}$ had a more crucial role in the bactericidal effect and GO-PcZr(Lys) $)_{2}$-Ag might have inactivated the serum complement.

The insignificant reduced bactericidal ability shown by GO-PcZr(Lys $)_{2}$-Ag-treated NHS (as illustrated in Figure 2A) was intensified by IR exposure (as illustrated in Figure 2C). In GO-PcZr(Lys) $)_{2}$-Ag-treated NHS that was subsequently irradiated, $43 \%$ bacterial survival was observed $(p=0.0142)$. In contrast, without IR irradiation survival was $98 \%$ ( $p>0.05$, no statistically significant difference between T0 and T60, as illustrated in Figure 2A). The role of light in reducing the number of bacteria was not observed in GO, GO-Ag, and GO-PcZr(Lys) ${ }_{2}$-exposed NHS (240\%, 49\% and 17\% survival, respectively, after IR irradiation, as illustrated in Figure 2C, $p>0.05$ ), because, without IR exposure the strain displayed a lower or similar survival rate $(150 \%, 23 \%$, and $27 \%$ after $60 \mathrm{~min}$ of incubation, as illustrated in Figure 2A). Summarizing the above, IR irradiation enhances bactericidal activity of serum in the case of the GO-PcZr(Lys) ${ }_{2}$.

This research showed that bacteria exposed to nanocomposites become more sensitive to serum action $(p<0.05$, as illustrated in Figure 4 A). Only $12 \%, 1 \%$, and $1 \%$ of bacteria exposed to GO-PcZr(Lys) $)_{2}-\mathrm{Ag}$, GO-Ag, and GO-PcZr(Lys) $)_{2}$ nanocomposites, respectively, survived the human serum activity. E. coli 6.2E showed high susceptibility to GO action with a survival rate of $0 \%$ after 30 -min incubation before the serum treatment (as illustrated in Figure 4A). This observation could be explained by the fact of changes appearing in the bacterial outer membrane, which facilitate complement activity. However, these changes caused by the nanocomponents are not crucial enough for cells to multiply again in iNHS (as illustrated in Figure 4B).

Bacteria exposed to serum survived action of pure GO, GO-PcZr(Lys) $)_{2}-\mathrm{Ag}$, and GO$\operatorname{PcZr}(\text { Lys })_{2}$ samples $(p>0.05$, as illustrated in Figure $6 \mathrm{~A})$. The strain exhibited $68 \%, 46 \%$, and $93 \%$ survival for GO-PcZr(Lys) ${ }_{2}-\mathrm{Ag}$, GO-PcZr(Lys) ${ }_{2}$, and GO, respectively, after $60 \mathrm{~min}$ of the experiment. Compared to the strain not treated with serum there was $19 \%, 13 \%$, and $79 \%$ survival in GO-PcZr(Lys) ${ }_{2}-\mathrm{Ag}$, GO-PcZr(Lys) ${ }_{2}$, and the GO nanocomponent mixed with NHS, respectively (as illustrated in Figure 1C). In contrast, bacteria also exposed to serum become more sensitive to the GO-Ag sample ( $p<0.0001$, as illustrated in Figure 6A) based on survival rate changes from $32 \%$ in nonserum-treated conditions (as illustrated in Figure 1C) to $1 \%$ survival after serum treatment (as illustrated in Figure 6A).

In vivo cytotoxicity tests conducted for all designed graphite oxide nanocomposites in MIC concentrations revealed no toxic effect toward G. mellonella larvae. These results are the first step towards assessment of the suitability of these compounds for future testing with mammals and clinical use in humans. Cell cultures are used as an in vitro model for toxicity testing, but there is still a huge difference in comparison to that of whole animals [40]. G. mellonella larvae have the potential to predict the cytotoxic effects of 
various compounds in mammals [40-42]. The present study is the first one devoted to the examination of the cytotoxic activity of graphite oxide nanocomposites using G. mellonella larvae.

\section{Materials and Methods}

\subsection{Bacterial Strains}

In this study, E. coli 6.2E isolated from alveoli was used. This strain was provided by the Medical University of Lublin. The E. coli J53 (pMG101) silver-resistant E. coli K-12-J53 strain carrying the plasmid pMG101 from the National Collection of Type Cultures was used as a control in all experiments [43]. Results for this strain are presented in Appendix A.

\subsection{Nanocomposites}

The following samples described in detail previously $[9,29,44,45]$ were tested in this study: pure graphite oxide (GO), GO-PcZr(Lys) 2 -Ag (0.5 g/10 mL) (IV), GO-Ag $(0.5 \mathrm{~g} / 10 \mathrm{~mL})(\mathrm{V})$, and GO-PcZr(Lys) 2 (VI). A brief scheme of composites preparation is shown in Figure 9.

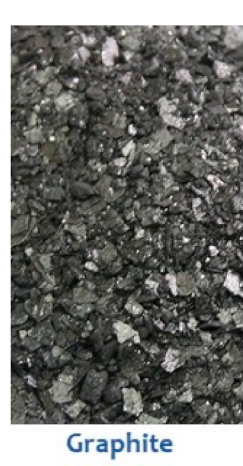

(A)

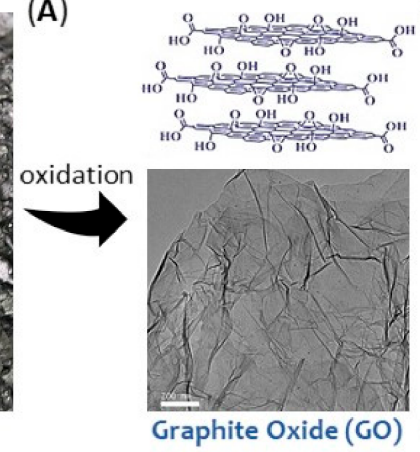

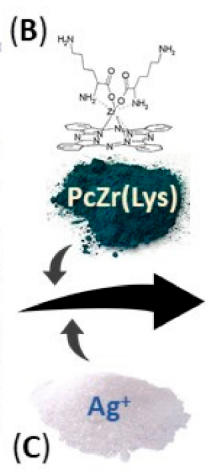

(C)

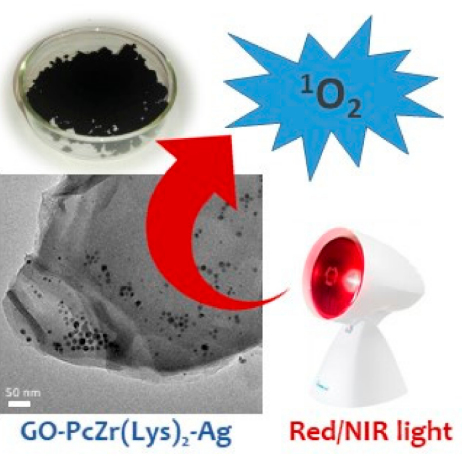

Figure 9. Scheme of GO-PcZr(Lys) $)_{2}$-Ag composite preparation. During first step of synthesis (A), reaction of graphite in strongly oxidizing conditions gives graphite oxide (GO). In next step (B), bis(lysinato)-PcZr is added in dimethylformamide and reaction proceeds in presence of dicyclohexylcarbodiimide used as a linker (GO-PcZr(Lys) $)_{2}$ ). Subsequently $(\mathbf{C})$, silver nitrate is added to aqueous suspension of GO-PcZr(Lys) ${ }_{2}$ and $\mathrm{Ag}^{+}$ions are reduced by the addition of ascorbic acid, resulting in a three-component composite (GO-(PcZr(Lys) $\left.{ }_{2}-\mathrm{Ag}\right)$.

\subsection{IR Exposure}

Infrared irradiation was repeated five times, with 2 min of exposure, at a distance of $50 \mathrm{~cm}$ from opened Eppendorf tubes containing a mixture of NHS and nanocomposites, and a 1 min short break with closed tubes.

\subsection{Normal Human Serum (NHS)}

NHS (Sigma-Aldrich), sterile-filtered, contained macromolecules, carrier proteins, attachment and spreading factors, low molecular weight nutrients, and hormones and growth factors [46]. The serum was frozen in $0.5-\mathrm{mL}$ and $1-\mathrm{mL}$ aliquots at $-70{ }^{\circ} \mathrm{C}$ for a period no longer than 2 months. Each aliquot of serum was used only once and thawed immediately before the experiment. Utilization of the residual NHS, iNHS and their mixtures with bacteria was carried out by the appropriate company, cooperating with the Department of Microbiology, Faculty of Biological Sciences, University of Wroclaw.

\subsection{Inactivated Normal Human Serum (iNHS)}

Serum inactivation was achieved by incubation at $56{ }^{\circ} \mathrm{C}$ for $30 \mathrm{~min}$. The aim of this treatment was to confirm that the complement is responsible for the bactericidal action of NHS and confirmation of the multiplication of bacterial strains. 


\subsection{Serum Bactericidal Assay}

The bactericidal activity of NHS was determined as described previously [47]. Briefly, LB broth (Biocorp) was inoculated to attain an optical density at $600 \mathrm{~nm}\left(\mathrm{OD}_{600}\right)$ of 0.1 with an overnight culture of $n=2 \mathrm{E}$. coli strains and incubated at $37^{\circ} \mathrm{C}$ with shaking at $250 \mathrm{rpm}$ in an incubator to $\mathrm{OD}_{600} 0.3$. Then cells were collected by centrifugation at $4000 \mathrm{rpm}$ for $20 \mathrm{~min}$ at $4{ }^{\circ} \mathrm{C}$. The pellets were resuspended in $3 \mathrm{~mL}$ of saline $(0.9 \% \mathrm{NaCl})$ and then diluted to a cell density of $10^{6} \mathrm{CFU} / \mathrm{mL}$ (colony forming units in $1 \mathrm{~mL}$ ). Aliquots of the cell suspension were mixed with an equal volume of NHS or iNHS at a final concentration of $25 \%(v / v)$ and incubated at $37^{\circ} \mathrm{C}$ for $0,15,30$, and $60 \mathrm{~min}$ in an incubator with shaking at $250 \mathrm{rpm}$. The nanocomposites were added in MIC concentration: GO-PcZr(Lys) $)_{2}-\mathrm{Ag}$ with or without IR light $64 \mu \mathrm{g} / \mathrm{mL}$; GO-Ag without IR light $512 \mu \mathrm{g} / \mathrm{mL}$, and with IR light $128 \mu \mathrm{g} / \mathrm{mL}$; GO-PcZr(Lys) ${ }_{2}$ and rGO with or without IR light $4096 \mu \mathrm{g} / \mathrm{mL}$. Every treatment was conducted at $37^{\circ} \mathrm{C}$ for 30 min prior the main serum bactericidal assay. The serial dilutions were plated onto LB agar (Biocorp) in duplicate or triplicate, incubated at $37^{\circ} \mathrm{C}$ for $24 \mathrm{~h}$, and $\mathrm{CFU} / \mathrm{mL}$ of bacteria exposed to the serum was calculated.

\subsection{Statistical Analysis}

Bacterial survival data at the defined time points were averaged, transformed from $\mathrm{CFU} / \mathrm{mL}$ values to percentage survival. The mean survival decrease or increase over time were studied using mixed ANOVA followed by Dunnett's multiple comparisons test (within groups, comparing T0 and T60 survival values) or Tukey's multiple comparisons test (between groups, comparing T60 survival values as presented in Appendix B; GraphPad Prism v. 9.1.1). Additionally, the resulting time series from all experiments were compared by calculating distances with the DTW algorithm and clustered using the fuzzy algorithm, both from the dtwclust 5.5.6 package in R [48]. Results for this analysis are presented in Appendix E. Missing values were interpolated using the imputeTS 3.1 package in R [49]. The fuzzy clusters were visualized using the linear projection tool from Orange 3 [50].

\subsection{Galleria mellonella Treatment Assays}

\subsubsection{G. mellonella Larvae Acquisition}

G. mellonella larvae were obtained from the culture of larvae at the Department of Microbiology of University of Wrocław. Healthy larvae were selected as those possessing a cream color with minimal speckling and no grey markings, proper firmness and elasticity, high motility, about $250 \mathrm{mg}$ in weight, and $2-3 \mathrm{~cm}$ in length [18,19]. Healthy larvae $(n=10)$ were selected and placed in separate Petri dishes.

\subsubsection{In Vivo Cytotoxicity Tests}

To test the toxic effect of tested graphite oxide nanocomposites, larvae $(n=10)$ were injected with appropriate probes: GO-PcZr(Lys) ${ }_{2}-\mathrm{Ag}$, GO-Ag, GO-PcZr(Lys) $)_{2}$, and GO, respectively. Compounds $(10 \mu \mathrm{L})$ were administered into the hemocoels through the last left proleg using a $25 \mu \mathrm{L}$ Hamilton syringe (Hamilton, Shanghai, People's Republic of China). Larvae were incubated at $37^{\circ} \mathrm{C}$ in the dark. Previously determined MIC concentrations of each tested nanocomposite were used for injection: GO-PcZr(Lys) ${ }_{2}-\mathrm{Ag} 64 \mu \mathrm{g} / \mathrm{mL} ; \mathrm{GO}-\mathrm{Ag}$ $512 \mu \mathrm{g} / \mathrm{mL}$; GO-PcZr(Lys) ${ }_{2}$ and rGO $4096 \mu \mathrm{g} / \mathrm{mL}$. Ten inoculated (sterile PBS) larvae were used as controls. The larvae were observed for survival every $24 \mathrm{~h}$ for 5 days. Larvae were considered dead when no response was observed following touch $[18,19,23]$. Obtained data were pooled from a minimum of three independent experiments.

\section{Conclusions}

The following conclusions can be made for the E. coli 6.2E bacterial strain tested in this work:

- GO-PcZr(Lys $)_{2}$, without IR irradiation enhance the antimicrobial efficacy of the human serum; 
- IR irradiation enhances bactericidal activity of human serum in the case of the GO$\operatorname{PcZr}(\text { Lys })_{2}$-Ag sample;

- bacteria exposed to nanocomposites become more sensitive to the action of human serum;

- bacteria exposed to human serum become more sensitive to the GO-Ag sample;

- the influence of GO nanocomposites on the antibacterial activity of human serum and the impact on the bacterial sensitivity to human serum after their contact with GO nanocomposites strongly depend on the physicochemical properties of GO nanocomposites;

- the designed graphite nanocomposites showed no cytotoxic effect toward Galleria mellonella larvae;

- in comparison to that of E. coli J53, antimicrobial efficacy of human serum depends on individual properties of bacteria.

Author Contributions: Conceptualization, G.B.-P., A.K. and K.D.M.; methodology: A.K., G.B.-P., K.D.M., M.K., M.W., B.D. and Y.G.; validation: K.D.M., M.W., B.D. and M.K.; formal analysis A.K., G.B.-P., K.D.M., M.W. and B.D.; field investigation A.K., G.B.-P., K.D.M., M.W. and B.D.; writing-original draft preparation, K.D.M., M.W., A.K., M.K., G.B.-P. and A.L.; writing-review and editing K.D.M., A.K., G.B.-P. and J.B.; visualization, K.D.M., M.W., M.K. and A.L. All authors read and agreed to the published version of the manuscript.

Funding: This work was partially supported by the National Science Centre [grant number2016/23/ B/ST5/02480]. Publication of this article in open access was financially supported by the Excellence Initiative-Research University (IDUB) program for the University of Wroclaw.

Institutional Review Board Statement: Not applicable.

Informed Consent Statement: Not applicable.

Data Availability Statement: Not applicable.

Acknowledgments: The authors thank Dominika Piątek and Izabela Korona-Głowniak (Medical University of Lublin) for providing strains for research. Authors also would like to thank to Paweł Migdał for invaluable help with larvae breeding.

Conflicts of Interest: The authors declare no conflict of interest.

\section{Appendix A}

Table A1. Bacterial survival experiments results expressed as CFU/mL values, measured in four timepoints $(0,15,30$, and $60 \mathrm{~min})$.

\begin{tabular}{ccccc}
\hline Replicate & T0 & T15 & T30 & T60 \\
\hline 6.2E+NHS & $582,000,000$ & $728,000,000$ & $61,000,000$ & $178,000,000$ \\
6.2E+NHS_2 & $795,000,000$ & $603,000,000$ & $608,000,000$ & $153,000,000$ \\
6.2E+NHS_3 & $58,000,000$ & $535,000,000$ & $718,000,000$ & $8,500,000$ \\
6.2E+iNHS & $463,000,000$ & $623,000,000$ & $453,000,000$ & $545,000,000$ \\
6.2E+iNHS_2 & $573,000,000$ & $493,000,000$ & $383,000,000$ & $825,000,000$ \\
6.2E+iNHS_3 & $508,000,000$ & $493,000,000$ & $355,000,000$ & $84,000,000$ \\
6.2E+GO & 62,000 & 0 & 0 & 0 \\
6.2E+GO_2 & 51,250 & 0 & 0 & 0 \\
6.2E+GO_3 & 76,000 & 0 & 0 & 0 \\
6.2E+IV & $3,680,000$ & $2,330,000$ & $2,300,000$ & $1,500,000$ \\
6.2E+IV_2 & $4,580,000$ & $3,530,000$ & $3,180,000$ & $2,600,000$ \\
6.2E+IV_3 & $4,680,000$ & $3,800,000$ & $2,600,000$ & $2,370,000$ \\
6.2E+V & $3,330,000$ & $2,030,000$ & $2,380,000$ & $1,330,000$ \\
6.2E+V_2 & $2,850,000$ & $2,200,000$ & $1,600,000$ & $1,650,000$ \\
6.2E+V_3 & $2,000,000$ & $1,880,000$ & $1,580,000$ & $1,950,000$ \\
6.2E+VI & $4,330,000$ & $8,380,000$ & $3,330,000$ & $4,500,000$ \\
\hline
\end{tabular}


Table A1. Cont.

\begin{tabular}{|c|c|c|c|c|}
\hline Replicate & T0 & T15 & T30 & T60 \\
\hline 6.2E+VI_2 & $3,670,000$ & $5,500,000$ & $4,830,000$ & $6,750,000$ \\
\hline 6.2E+VI_3 & $7,380,000$ & $5,170,000$ & $6,400,000$ & $5,330,000$ \\
\hline 6.2E+NHS+GO & $3,830,000$ & $4,830,000$ & $5,170,000$ & $4,330,000$ \\
\hline 6.2E+NHS+GO_2 & $9,630,000$ & $4,170,000$ & $7,630,000$ & $6,330,000$ \\
\hline 6.2E+NHS+GO_3 & $8,130,000$ & $10,200,000$ & & $4,670,000$ \\
\hline 6.2E+NHS+IV & $655,000,000$ & $645,000,000$ & $438,000,000$ & $145,000,000$ \\
\hline 6.2E+NHS+IV_2 & $713,000,000$ & $560,000,000$ & $463,000,000$ & $173,000,000$ \\
\hline $6.2 \mathrm{E}+\mathrm{NHS}+\mathrm{IV} \_3$ & $680,000,000$ & $538,000,000$ & $408,000,000$ & $75,000,000$ \\
\hline 6.2E+NHS+V & $603,000,000$ & $298,000,000$ & $205,000,000$ & $160,000,000$ \\
\hline $6.2 \mathrm{E}+\mathrm{NHS}+\mathrm{V} \_2$ & $735,000,000$ & $520,000,000$ & $323,000,000$ & $193,000,000$ \\
\hline $6.2 \mathrm{E}+\mathrm{NHS}+\mathrm{V} \_3$ & $580,000,000$ & $540,000,000$ & $623,000,000$ & $185,000,000$ \\
\hline $6.2 \mathrm{E}+\mathrm{NHS}+\mathrm{V} \_4$ & $718,000,000$ & $423,000,000$ & $445,000,000$ & $320,000,000$ \\
\hline $6.2 \mathrm{E}+\mathrm{NHS}+\overline{\mathrm{VI}}$ & $6,630,000$ & $3,500,000$ & $2,920,000$ & $1,290,000$ \\
\hline 6.2E+NHS+VI_2 & $6,000,000$ & $8,500,000$ & $2,920,000$ & $1,140,000$ \\
\hline 6.2E+NHS+VI_3 & $8,000,000$ & $3,990,000$ & 525,000 & 100,000 \\
\hline 6.2E+GO+IR & $2,333,333$ & 0 & 0 & 0 \\
\hline $6.2 \mathrm{E}+\mathrm{GO}+\mathrm{IR} \_2$ & 25,700 & 0 & 0 & 0 \\
\hline 6.2E+GO+IR_3 & 19,500 & 0 & 0 & 0 \\
\hline $6.2 \mathrm{E}+\mathrm{IV}+\mathrm{IR}$ & $2,670,000$ & $2,680,000$ & $2,080,000$ & 650,000 \\
\hline $6.2 \mathrm{E}+\mathrm{IV}+\mathrm{IR} \_2$ & $2,300,000$ & $2,900,000$ & $1,850,000$ & 200,000 \\
\hline $6.2 \mathrm{E}+\mathrm{IV}+\mathrm{IR} \_3$ & $2,230,000$ & $2,630,000$ & $1,800,000$ & 400,000 \\
\hline $6.2 \mathrm{E}+\mathrm{V}+\mathrm{IR}$ & $2,000,000$ & $2,630,000$ & $2,400,000$ & $1,480,000$ \\
\hline $6.2 \mathrm{E}+\mathrm{V}+\mathrm{IR} \_2$ & $2,470,000$ & $1,450,000$ & $1,530,000$ & 920,000 \\
\hline $6.2 \mathrm{E}+\mathrm{V}+\mathrm{IR} \_3$ & $2,500,000$ & $2,180,000$ & $1,530,000$ & 900,000 \\
\hline $6.2 \mathrm{E}+\mathrm{VI}+\mathrm{IR}$ & $5,250,000$ & $7,500,000$ & $7,700,000$ & $3,330,000$ \\
\hline $6.2 \mathrm{E}+\mathrm{VI}+\mathrm{IR} \_2$ & $6,750,000$ & $7,080,000$ & $4,670,000$ & $8,700,000$ \\
\hline 6.2E+VI+IR_3 & $5,880,000$ & $4,880,000$ & $3,170,000$ & $8,630,000$ \\
\hline$(\mathrm{NHS}+\mathrm{GO})+6.2 \mathrm{E}$ & 51,250 & 61,250 & 67,500 & 78,750 \\
\hline$(\mathrm{NHS}+\mathrm{GO})+6.2 \mathrm{E} \_2$ & 45,000 & 107,500 & 65,000 & 100,000 \\
\hline$(\mathrm{NHS}+\mathrm{GO})+6.2 \mathrm{E} \_3$ & 118,000 & 86,000 & 358,000 & 86,250 \\
\hline$(\mathrm{NHS}+\mathrm{IV})+6.2 \mathrm{E}$ & $6,100,000$ & $4,330,000$ & $7,450,000$ & $5,630,000$ \\
\hline$(\mathrm{NHS}+\mathrm{IV})+6.2 \mathrm{E} \_2$ & $7,800,000$ & $8,030,000$ & $8,430,000$ & $7,880,000$ \\
\hline$(\mathrm{NHS}+\mathrm{IV})+6.2 \mathrm{E} \_3$ & $5,950,000$ & $6,080,000$ & $5,680,000$ & $6,000,000$ \\
\hline$(\mathrm{NHS}+\mathrm{V})+6.2 \mathrm{E}$ & $5,280,000$ & $4,850,000$ & $1,780,000$ & 50,000 \\
\hline$(\mathrm{NHS}+\mathrm{V})+6.2 \mathrm{E} \_2$ & $6,720,000$ & $4,900,000$ & $4,350,000$ & 0 \\
\hline$(\mathrm{NHS}+\mathrm{V})+6.2 \mathrm{E} \_3$ & $5,870,000$ & $6,030,000$ & $1,730,000$ & $4,000,000$ \\
\hline$(\mathrm{NHS}+\mathrm{VI})+6.2 \overline{\mathrm{E}}$ & 88,000 & 75,000 & 25,750 & 13,300 \\
\hline$(\mathrm{NHS}+\mathrm{VI})+6.2 \mathrm{E} \_2$ & $6,333,333$ & $3,333,333$ & 17,800 & 31,000 \\
\hline$(\mathrm{NHS}+\mathrm{VI})+6.2 \mathrm{E} \_3$ & 72,500 & 61,250 & 29,000 & 12,625 \\
\hline$(\mathrm{iNHS}+\mathrm{GO})+6.2 \mathrm{E}$ & $9,100,000$ & $5,000,000$ & $10,200,000$ & $4,500,000$ \\
\hline (iNHS+GO)+6.2E_2 & $9,800,000$ & $14,600,000$ & $44,300,000$ & $9,630,000$ \\
\hline$(\mathrm{iNHS}+\mathrm{IV})+6.2 \mathrm{E}$ & $475,000,000$ & $665,000,000$ & $510,000,000$ & $410,000,000$ \\
\hline$(\mathrm{iNHS}+\mathrm{IV})+6.2 \mathrm{E} \_2$ & $662,000,000$ & $475,000,000$ & $578,000,000$ & $427,000,000$ \\
\hline (iNHS+IV)+6.2E_3 & $388,000,000$ & $585,000,000$ & $618,000,000$ & $297,000,000$ \\
\hline$(\mathrm{iNHS}+\mathrm{IV})+6.2 \mathrm{E} \_4$ & $253,000,000$ & $410,000,000$ & $425,000,000$ & $393,000,000$ \\
\hline (iNHS+IV)+6.2E_5 & $395,000,000$ & $443,000,000$ & $470,000,000$ & $330,000,000$ \\
\hline (iNHS+IV)+6.2E_6 & $583,000,000$ & $318,000,000$ & $315,000,000$ & $370,000,000$ \\
\hline$(\mathrm{iNHS}+\mathrm{V})+6.2 \mathrm{E}$ & $535,000,000$ & $510,000,000$ & $630,000,000$ & $278,000,000$ \\
\hline$(\mathrm{iNHS}+\mathrm{V})+6.2 \mathrm{E} \_2$ & $398,000,000$ & $373,000,000$ & $418,000,000$ & $140,000,000$ \\
\hline$(\mathrm{iNHS}+\mathrm{V})+6.2 \mathrm{E} \_3$ & $347,000,000$ & $505,000,000$ & $390,000,000$ & $85,000,000$ \\
\hline$(\mathrm{iNHS}+\mathrm{VI})+6.2 \mathrm{E}$ & $9,380,000$ & $5,000,000$ & $7,700,000$ & $7,700,000$ \\
\hline (iNHS+VI)+6.2E_2 & $8,900,000$ & $10,800,000$ & $9,400,000$ & $28,300,000$ \\
\hline$(\mathrm{NHS}+\mathrm{GO})+6.2 \mathrm{E}+\mathrm{IR}$ & 95,000 & & 132,500 & 284,000 \\
\hline$(\mathrm{NHS}+\mathrm{GO})+6.2 \mathrm{E}+\mathrm{IR} \_2$ & $3,666,667$ & 60,000 & 58,750 & $6,666,667$ \\
\hline$(\mathrm{NHS}+\mathrm{IV})+6.2 \mathrm{E}+\mathrm{IR}$ & $4,350,000$ & $2,480,000$ & $3,730,000$ & $1,530,000$ \\
\hline$(\mathrm{NHS}+\mathrm{IV})+6.2 \mathrm{E}+\mathrm{IR} \_2$ & $4,670,000$ & $6,730,000$ & $4,400,000$ & $2,430,000$ \\
\hline$(\mathrm{NHS}+\mathrm{IV})+6.2 \mathrm{E}+\mathrm{IR} \_3$ & $4,100,000$ & $1,950,000$ & $2,600,000$ & $1,680,000$ \\
\hline$(\mathrm{NHS}+\mathrm{V})+6.2 \mathrm{E}+\mathrm{IR}$ & $3,980,000$ & $1,830,000$ & $2,100,000$ & $1,470,000$ \\
\hline
\end{tabular}


Table A1. Cont.

\begin{tabular}{|c|c|c|c|c|}
\hline Replicate & T0 & T15 & T30 & T60 \\
\hline$(\mathrm{NHS}+\mathrm{V})+6.2 \mathrm{E}+\mathrm{IR} \_2$ & $3,470,000$ & $2,680,000$ & $4,200,000$ & $1,170,000$ \\
\hline$(\mathrm{NHS}+\mathrm{V})+6.2 \mathrm{E}+\mathrm{IR} \_3$ & $2,530,000$ & $1,580,000$ & $2,670,000$ & $1,930,000$ \\
\hline$(\mathrm{NHS}+\mathrm{VI})+6.2 \mathrm{E}+\mathrm{IR}$ & $7,166,667$ & 85,000 & $2,333,333$ & 14,100 \\
\hline$(\mathrm{NHS}+\mathrm{VI})+6.2 \mathrm{E}+\mathrm{IR} \_2$ & 101,000 & 102,000 & 92,000 & 20,500 \\
\hline$(\mathrm{NHS}+\mathrm{VI})+6.2 \mathrm{E}+\mathrm{IR} \_3$ & 75,000 & 24,000 & 18,250 & $7,833,333$ \\
\hline (iNHS+GO)+6.2E+IR & $24,200,000$ & $8,250,000$ & $7,800,000$ & $23,800,000$ \\
\hline$(\mathrm{iNHS}+\mathrm{GO})+6.2 \mathrm{E}+\mathrm{IR} \_2$ & $8,130,000$ & $14,600,000$ & $9,380,000$ & $7,000,000$ \\
\hline$(\mathrm{iNHS}+\mathrm{IV})+6.2 \mathrm{E}+\mathrm{IR}$ & $370,000,000$ & $368,000,000$ & $373,000,000$ & $687,000,000$ \\
\hline$(\mathrm{iNHS}+\mathrm{IV})+6.2 \mathrm{E}+\mathrm{IR} \_2$ & $370,000,000$ & $500,000,000$ & $423,000,000$ & $530,000,000$ \\
\hline$(\mathrm{iNHS}+\mathrm{IV})+6.2 \mathrm{E}+\mathrm{IR} \_3$ & $398,000,000$ & $508,000,000$ & $473,000,000$ & $517,000,000$ \\
\hline$(\mathrm{iNHS}+\mathrm{V})+6.2 \mathrm{E}+\mathrm{IR}$ & $180,000,000$ & $363,000,000$ & $233,000,000$ & $530,000,000$ \\
\hline$(\mathrm{iNHS}+\mathrm{V})+6.2 \mathrm{E}+\mathrm{IR} \_2$ & $178,000,000$ & $323,000,000$ & $347,000,000$ & $597,000,000$ \\
\hline$(\mathrm{iNHS}+\mathrm{V})+6.2 \mathrm{E}+\mathrm{IR} \_3$ & $153,000,000$ & $275,000,000$ & $320,000,000$ & $680,000,000$ \\
\hline$(\mathrm{iNHS}+\mathrm{VI})+6.2 \mathrm{E}+\mathrm{IR}$ & $6,170,000$ & $8,630,000$ & $10,800,000$ & $10,900,000$ \\
\hline$(\mathrm{iNHS}+\mathrm{VI})+6.2 \mathrm{E}+\mathrm{IR} \_2$ & 8500,000 & $5,670,000$ & $7,000,000$ & $22,800,000$ \\
\hline$(\mathrm{iNHS}+\mathrm{VI})+6.2 \mathrm{E}+\mathrm{IR} \_3$ & 7500,000 & $9,100,000$ & $7,900,000$ & $6,630,000$ \\
\hline$(6.2 \mathrm{E}+\mathrm{GO})+\mathrm{NHS}$ & 0 & 0 & 0 & 0 \\
\hline$(6.2 \mathrm{E}+\mathrm{GO})+\mathrm{NHS} \_2$ & 0 & 0 & 0 & 0 \\
\hline$(6.2 \mathrm{E}+\mathrm{IV})+\mathrm{NHS}$ & $270,000,000$ & $180,000,000$ & $15,000,000$ & $25,500,000$ \\
\hline$(6.2 \mathrm{E}+\mathrm{IV})+\mathrm{NHS} \_2$ & $353,000,000$ & $318,000,000$ & $90,000,000$ & $21,800,000$ \\
\hline$(6.2 \mathrm{E}+\mathrm{IV})+\mathrm{NHS} \_3$ & $177,000,000$ & $153,000,000$ & $100,000,000$ & $33,500,000$ \\
\hline$(6.2 \mathrm{E}+\mathrm{V})+\mathrm{NHS}$ & $265,000,000$ & $117,000,000$ & $15,000,000$ & $4,000,000$ \\
\hline$(6.2 \mathrm{E}+\mathrm{V})+\mathrm{NHS} \_2$ & $232,000,000$ & $110,000,000$ & $25,000,000$ & $2,000,000$ \\
\hline$(6.2 \mathrm{E}+\mathrm{V})+\mathrm{NHS} 33$ & $298,000,000$ & $107,000,000$ & 0 & $3,000,000$ \\
\hline$(6.2 \mathrm{E}+\mathrm{VI})+\mathrm{NHS}$ & $7,130,000$ & $1,840,000$ & 425,000 & 200,000 \\
\hline$(6.2 \mathrm{E}+\mathrm{VI})+\mathrm{NHS} \_2$ & $7,000,000$ & $1,290,000$ & 0 & 0 \\
\hline$(6.2 \mathrm{E}+\mathrm{GO})+\mathrm{iNHS}$ & 0 & 0 & 0 & 0 \\
\hline$(6.2 \mathrm{E}+\mathrm{GO})+\mathrm{iNHS} \_2$ & 0 & 0 & 0 & 0 \\
\hline$(6.2 \mathrm{E}+\mathrm{GO})+\mathrm{iNHS} 33$ & 0 & 0 & 0 & 0 \\
\hline$(6.2 \mathrm{E}+\mathrm{IV})+\mathrm{iNHS}$ & $325,000,000$ & $168,000,000$ & $18,000,000$ & $3,500,000$ \\
\hline$(6.2 \mathrm{E}+\mathrm{IV})+\mathrm{iNHS} \_2$ & $348,000,000$ & $298,000,000$ & $488,000,000$ & $623,000,000$ \\
\hline$(6.2 \mathrm{E}+\mathrm{IV})+\mathrm{iNHS} 3$ & $144,000,000$ & $227,000,000$ & $18,000,000$ & $275,000,000$ \\
\hline$(6.2 \mathrm{E}+\mathrm{V})+\mathrm{iNHS}$ & $265,000,000$ & $117,000,000$ & $1,500,000$ & 40,000 \\
\hline$(6.2 \mathrm{E}+\mathrm{V})+\mathrm{iNHS} 22$ & $232,000,000$ & $11,000,000$ & $2,500,000$ & 20,000 \\
\hline$(6.2 \mathrm{E}+\mathrm{V})+\mathrm{iNHS} 33$ & $298,000,000$ & $107,000,000$ & 0 & 30,000 \\
\hline$(6.2 \mathrm{E}+\mathrm{VI})+\mathrm{iNHS}$ & $63,750,000$ & $43,333,330,000$ & $6,250,000$ & 80,000 \\
\hline$(6.2 \mathrm{E}+\mathrm{VI})+\mathrm{iNHS} \_2$ & $61,250,000$ & $53,333,330,000$ & $5,750,000$ & $63,750,000$ \\
\hline$(\mathrm{NHS}+6.2 \mathrm{E})+\mathrm{GO}$ & 180,000 & $18,333,330,000$ & $1,950,000$ & 190,000 \\
\hline$(\mathrm{NHS}+6.2 \mathrm{E})+\mathrm{GO} \_2$ & $19,250,000$ & $42,583,330,000$ & $14,333,330,000$ & $1,580,000$ \\
\hline$(\mathrm{NHS}+6.2 \mathrm{E})+\mathrm{GO}_{-} 3$ & $1,830,000$ & $183,750,000$ & 1740,000 & $1,670,000$ \\
\hline$(\mathrm{NHS}+6.2 \mathrm{E})+\mathrm{IV}$ & $365,000,000$ & $338,000,000$ & $245,000,000$ & $133,000,000$ \\
\hline$(\mathrm{NHS}+6.2 \mathrm{E})+\mathrm{IV} \_2$ & $375,000,000$ & $327,000,000$ & $253,000,000$ & $23,000,000$ \\
\hline$(\mathrm{NHS}+6.2 \mathrm{E})+\mathrm{IV} \_3$ & $233,000,000$ & $20,500,0000$ & $235,000,000$ & $248,000,000$ \\
\hline$(\mathrm{NHS}+6.2 \mathrm{E})+\mathrm{V}$ & $43,000,000$ & $42,500,000$ & $4,500,000$ & 650,000 \\
\hline$(\mathrm{NHS}+6.2 \mathrm{E})+\mathrm{V} \_2$ & $58,000,000$ & $32,500,000$ & 300,000 & 90,000 \\
\hline$(\mathrm{NHS}+6.2 \mathrm{E})+\mathrm{V} \_3$ & $533,000,000$ & $2,500,000$ & $2,500,000$ & 250,000 \\
\hline$(\mathrm{NHS}+6.2 \mathrm{E})+\mathrm{VI}$ & $1,240,000$ & $1,390,000$ & 9000 & 325,000 \\
\hline$(\mathrm{NHS}+6.2 \mathrm{E})+\mathrm{VI} \_2$ & $3,520,000$ & $1,740,000$ & 140,000 & $3,140,000$ \\
\hline (NHS+6.2E)+VI_3 & 860,000 & $5,250,000$ & $32,666,670,000$ & $1,910,000$ \\
\hline (iNHS+6.2E)+GO & 840,000 & 730,000 & $5,750,000$ & $48,333,330,000$ \\
\hline$(\mathrm{iNHS}+6.2 \mathrm{E})+\mathrm{GO} \_2$ & $91,250,000$ & $12,700,000$ & $83,750,000$ & 70,000 \\
\hline$(\mathrm{iNHS}+6.2 \mathrm{E})+\mathrm{GO} 3$ & 950,000 & $9,250,000$ & $260,833,300,000$ & $81,250,000$ \\
\hline$(\mathrm{iNHS}+6.2 \mathrm{E})+\mathrm{IV}$ & $743,000,000$ & $478,000,000$ & $417,000,000$ & $477,000,000$ \\
\hline$(\mathrm{iNHS}+6.2 \mathrm{E})+\mathrm{IV} \_2$ & $413,000,000$ & $383,000,000$ & $653,000,000$ & $69,000,000$ \\
\hline$(\mathrm{iNHS}+6.2 \mathrm{E})+\mathrm{IV} \_3$ & $402,000,000$ & $345,000,000$ & $61,000,000$ & $547,000,000$ \\
\hline$(\mathrm{iNHS}+6.2 \mathrm{E})+\mathrm{V}$ & $467,000,000$ & $605,000,000$ & $58,000,000$ & $658,000,000$ \\
\hline
\end{tabular}


Table A1. Cont.

\begin{tabular}{|c|c|c|c|c|}
\hline Replicate & T0 & T15 & T30 & T60 \\
\hline$(\mathrm{iNHS}+6.2 \mathrm{E})+\mathrm{V} \_2$ & $692,000,000$ & $44,000,000$ & $133,000,000$ & $565,000,000$ \\
\hline$(\mathrm{iNHS}+6.2 \mathrm{E})+\mathrm{V} \_3$ & $402,000,000$ & $455,000,000$ & $245,000,000$ & $423,000,000$ \\
\hline$(\mathrm{iNHS}+6.2 \mathrm{E})+\mathrm{VI}$ & $166,250,000$ & 920,000 & 950,000 & 770,000 \\
\hline (iNHS+6.2E)+VI_2 & $68,333,330,000$ & $262,500,000$ & $213,571,400,000$ & $7,250,000$ \\
\hline (iNHS+6.2E)+VI_3 & 960,000 & $84,166,670,000$ & 990,000 & $225,714,300,000$ \\
\hline $\mathrm{J} 53+\mathrm{NHS}$ & $7,170,000$ & $6,400,000$ & 0 & 0 \\
\hline J53+NHS_2 & $7,950,000$ & $5,500,000$ & 0 & 0 \\
\hline J53+NHS_3 & $7,120,000$ & $7,450,000$ & 0 & 0 \\
\hline $\mathrm{J} 53+\mathrm{iNHS}$ & $6,230,000$ & $6,130,000$ & $7,830,000$ & $170,000,000$ \\
\hline J53+iNHS_2 & $7,900,000$ & $5,950,000$ & $6,380,000$ & $1,450,000,000$ \\
\hline J53+iNHS_3 & $7,320,000$ & $4,280,000$ & $6,580,000$ & $120,000,000$ \\
\hline $\mathrm{J} 53+\mathrm{GO}$ & 143,000 & $1,566,667$ & 78,750 & 15,000 \\
\hline J53+GO_2 & 140,000 & 0 & 0 & 0 \\
\hline J53+GO_3 & 102,500 & $6,333,333$ & 0 & 0 \\
\hline $\mathrm{J} 53+\mathrm{IV}$ & $5,050,000$ & $1,540,000,000$ & $1,830,000,000$ & $1,290,000,000$ \\
\hline J53+IV_2 & $6,830,000$ & $1,140,000,000$ & $1,860,000,000$ & $1,290,000,000$ \\
\hline $\mathrm{J} 53+\mathrm{IV} \_3$ & $7,250,000$ & $1,080,000,000$ & $1,680,000,000$ & $1,630,000,000$ \\
\hline $\mathrm{J} 53+\overline{\mathrm{V}}$ & $8,750,000$ & $2,390,000,000$ & $4,430,000$ & $4,750,000$ \\
\hline $\mathrm{J} 53+\mathrm{V} \_2$ & $5,750,000$ & $1,050,000,000$ & $6,130,000$ & $5,850,000$ \\
\hline $\mathrm{J} 53+\mathrm{V} \_3$ & $7,580,000$ & $1,580,000,000$ & $8,850,000$ & $6,000,000$ \\
\hline $\mathrm{J} 53+\mathrm{VI}$ & $1,583,333$ & 130,000 & 106,250 & 193,000 \\
\hline J53+VI_2 & $6,666,667$ & 45,000 & $4,166,667$ & 57,500 \\
\hline J53+VI_3 & 129,000 & 85,000 & 98,750 & 93,000 \\
\hline $\mathrm{J} 53+\mathrm{NHS}+\mathrm{GO}$ & 85,000 & 0 & 0 & 0 \\
\hline J53+NHS+GO_2 & 0 & 0 & 0 & 0 \\
\hline $\mathrm{J} 53+\mathrm{NHS}+\mathrm{GO} 3$ & 109,000 & 61,250 & 0 & 0 \\
\hline $\mathrm{J} 53+\mathrm{NHS}+\mathrm{IV}$ & $5,580,000$ & $1,090,000,000$ & $1,900,000$ & 7500 \\
\hline J53+NHS+IV_2 & $7,720,000$ & $1,280,000,000$ & $6,230,000$ & 155,000 \\
\hline J53+NHS+IV_3 & $8,350,000$ & $1,310,000,000$ & $4,400,000$ & 305,000 \\
\hline $\mathrm{J} 53+\mathrm{NHS}+\mathrm{IV} \_4$ & $4,730,000$ & $3,830,000$ & 0 & 0 \\
\hline J53+NHS+IV_5 & $6,200,000$ & $7,030,000$ & 0 & 0 \\
\hline J53+NHS+IV_6 & $7,620,000$ & $6,530,000$ & 0 & 0 \\
\hline $\mathrm{J} 53+\mathrm{NHS}+\mathrm{V}$ & $6,130,000$ & 0 & 0 & 0 \\
\hline J53+NHS+V_2 & $7,770,000$ & 0 & 0 & 0 \\
\hline J53+NHS+V_3 & $7,340,000$ & 0 & 0 & 0 \\
\hline $\mathrm{J} 53+\mathrm{NHS}+\mathrm{V}_{-} 4$ & $7,330,000$ & 0 & 0 & 0 \\
\hline $\mathrm{J} 53+\mathrm{NHS}+\mathrm{VI}$ & 138,000 & 0 & 0 & 0 \\
\hline J53+NHS+VI_2 & $8,166,667$ & 0 & 0 & 0 \\
\hline J53+NHS+VI_3 & 75,000 & 0 & 0 & 0 \\
\hline $\mathrm{J} 53+\mathrm{GO}+\mathrm{IR}$ & $1,991,667$ & 139,000 & 67,500 & $1,666,667$ \\
\hline J53+GO+IR_2 & $1,383,333$ & 0 & 0 & 0 \\
\hline J53+GO+IR_3 & 116,250 & 35,000 & 45,000 & 0 \\
\hline $\mathrm{J} 53+\mathrm{IV}+\mathrm{IR}$ & $7,400,000$ & $1,330,000,000$ & $1,350,000,000$ & $2,010,000,000$ \\
\hline J53+IV+IR_2 & $6,370,000$ & $1,210,000,000$ & $1,280,000,000$ & $1,850,000,000$ \\
\hline $\mathrm{J} 53+\mathrm{IV}+\mathrm{IR} \_3$ & $7,870,000$ & $1,760,000,000$ & $1,450,000,000$ & $1,610,000,000$ \\
\hline $\mathrm{J} 53+\mathrm{V}+\mathrm{IR}$ & $6,870,000$ & $6,300,000$ & $7,750,000$ & $6,000,000$ \\
\hline J53+V+IR_2 & $4,950,000$ & $6,480,000$ & $7,330,000$ & $4,960,000$ \\
\hline $\mathrm{J} 53+\mathrm{V}+\mathrm{IR} \_3$ & $6,300,000$ & $4,730,000$ & $7,300,000$ & $5,940,000$ \\
\hline $\mathrm{J} 53+\mathrm{VI}+\mathrm{IR}$ & $1,733,333$ & 145,000 & 139,000 & 83,000 \\
\hline J53+VI+IR_2 & 74,000 & 60,000 & 67,500 & 35,000 \\
\hline J53+VI+IR_3 & 60,000 & 76,250 & 60,000 & $4,333,333$ \\
\hline$(\mathrm{NHS}+\mathrm{GO})+\mathrm{J} 53$ & 129,000 & 0 & 0 & 0 \\
\hline$(\mathrm{NHS}+\mathrm{GO})+\mathrm{J} 53 \_2$ & 0 & 0 & 0 & 0 \\
\hline$(\mathrm{NHS}+\mathrm{GO})+\mathrm{J} 53$ _3 & 154,000 & 0 & 0 & 0 \\
\hline$(\mathrm{NHS}+\mathrm{IV})+\mathrm{J} 53$ & $7,970,000$ & $6,930,000$ & 75,000 & 0 \\
\hline (NHS+IV)+J53_2 & $8,350,000$ & $7,480,000$ & 25,000 & 0 \\
\hline
\end{tabular}


Table A1. Cont.

\begin{tabular}{|c|c|c|c|c|}
\hline Replicate & T0 & T15 & T30 & T60 \\
\hline$(\mathrm{NHS}+\mathrm{IV})+\mathrm{J} 53$ _3 & $8,630,000$ & $7,980,000$ & 50,000 & 0 \\
\hline$(\mathrm{NHS}+\mathrm{V})+\mathrm{J} 53$ & $6,200,000$ & 0 & 0 & 0 \\
\hline$(\mathrm{NHS}+\mathrm{V})+\mathrm{J} 53 \_2$ & $6,100,000$ & 0 & 0 & 0 \\
\hline$(\mathrm{NHS}+\mathrm{V})+\mathrm{J} 53 \_3$ & $7,080,000$ & 0 & 0 & 0 \\
\hline$(\mathrm{NHS}+\mathrm{V})+\mathrm{J} 53 \_4$ & $7,530,000$ & 0 & 0 & 0 \\
\hline$(\mathrm{NHS}+\mathrm{V})+\mathrm{J} 53 \_5$ & $7,430,000$ & $3,480,000$ & & 550,000 \\
\hline$(\mathrm{NHS}+\mathrm{V})+\mathrm{J} 53 \_6$ & $6,800,000$ & $3,250,000$ & $4,130,000$ & 500,000 \\
\hline$(\mathrm{NHS}+\mathrm{VI})+\mathrm{J} 53$ & $2,058,333$ & 0 & 0 & 0 \\
\hline$(\mathrm{NHS}+\mathrm{VI})+\mathrm{J} 53 \_2$ & 114,000 & 0 & 0 & 0 \\
\hline$(\mathrm{NHS}+\mathrm{VI})+\mathrm{J} 53 \_3$ & 87,500 & 0 & 0 & 0 \\
\hline (iNHS+GO)+J53 & 237,500 & $2,466,667$ & & $2,333,333$ \\
\hline (iNHS+GO)+J53_2 & 105,000 & $1,358,333$ & 150,000 & $3,833,333$ \\
\hline (iNHS+GO)+J53_3 & 83,750 & 760,00 & 146,000 & 145,000 \\
\hline (iNHS+IV)+J53 & $6,870,000$ & $6,500,000$ & $5,400,000$ & $8,880,000$ \\
\hline (iNHS+IV)+J53_2 & $7,300,000$ & $7,550,000$ & $4,500,000$ & $3,350,000$ \\
\hline$(\mathrm{iNHS}+\mathrm{IV})+\mathrm{J} 53 \_3$ & $6,250,000$ & $6,880,000$ & $4,330,000$ & $6,100,000$ \\
\hline$(\mathrm{iNHS}+\mathrm{V})+\mathrm{J} 53$ & $5,700,000$ & $1,490,000,000$ & $1,870,000,000$ & $3,250,000$ \\
\hline$(\mathrm{iNHS}+\mathrm{V})+\mathrm{J} 53 \_2$ & $7,830,000$ & $1,280,000,000$ & $1,950,000,000$ & $2,600,000$ \\
\hline$(\mathrm{iNHS}+\mathrm{V})+\mathrm{J} 53$ _3 & $7,080,000$ & $1,290,000,000$ & $1,290,000,000$ & $3,600,000$ \\
\hline$(\mathrm{iNHS}+\mathrm{V})+\mathrm{J} 53 \_4$ & $6,350,000$ & $1,550,000,000$ & $1,260,000,000$ & $2,700,000$ \\
\hline$(\mathrm{iNHS}+\mathrm{V})+\mathrm{J} 53 \_5$ & $4,480,000$ & $1,460,000,000$ & $1,570,000,000$ & $2,150,000$ \\
\hline$(\mathrm{iNHS}+\mathrm{V})+\mathrm{J} 53 \_6$ & $4,650,000$ & $1,200,000,000$ & $1,270,000,000$ & $2,700,000$ \\
\hline (iNHS+VI)+J53 & $1,666,667$ & 132,000 & 123,750 & 155,000 \\
\hline (iNHS+VI)+J53_2 & $8,666,667$ & $5,833,333$ & 99,000 & 130,000 \\
\hline (iNHS+VI)+J53_3 & 89,000 & $5,833,333$ & 89,000 & 130,000 \\
\hline$(\mathrm{NHS}+\mathrm{GO})+\mathrm{J} 53+\mathrm{IR}$ & 0 & 0 & 0 & 0 \\
\hline$(\mathrm{NHS}+\mathrm{GO})+\mathrm{J} 53+\mathrm{IR} \_2$ & 0 & 0 & 0 & 0 \\
\hline (NHS+GO)+J53+IR_3 & $9,083,333$ & 0 & 0 & 0 \\
\hline$(\mathrm{NHS}+\mathrm{IV})+\mathrm{J} 53+\mathrm{IR}$ & $5,420,000$ & $5,000,000$ & $3,500,000$ & $3,010,000$ \\
\hline$(\mathrm{NHS}+\mathrm{IV})+\mathrm{J} 53+\mathrm{IR} \_2$ & $5,200,000$ & $1,000,000$ & 500,000 & 653,000 \\
\hline$(\mathrm{NHS}+\mathrm{IV})+\mathrm{J} 53+\mathrm{IR} \_3$ & $6,000,000$ & 0 & 0 & 0 \\
\hline$(\mathrm{NHS}+\mathrm{IV})+\mathrm{J} 53+\mathrm{IR} \_4$ & $5,180,000$ & 0 & 0 & 0 \\
\hline$(\mathrm{NHS}+\mathrm{IV})+\mathrm{J} 53+\mathrm{IR} \_5$ & $6,100,000$ & 0 & 0 & 0 \\
\hline$(\mathrm{NHS}+\mathrm{V})+\mathrm{J} 53+\mathrm{IR}$ & 333,000 & 0 & 0 & 0 \\
\hline$(\mathrm{NHS}+\mathrm{V})+\mathrm{J} 53+\mathrm{IR} \_2$ & 133,000 & 0 & 0 & 0 \\
\hline$(\mathrm{NHS}+\mathrm{V})+\mathrm{J} 53+\mathrm{IR} \_3$ & 533,000 & 0 & 0 & 0 \\
\hline$(\mathrm{NHS}+\mathrm{VI})+\mathrm{J} 53+\mathrm{IR}$ & 157,500 & 0 & 0 & 0 \\
\hline$(\mathrm{NHS}+\mathrm{VI})+\mathrm{J} 53+\mathrm{IR} \_2$ & 90,000 & $1,108,333$ & 62,500 & 51,250 \\
\hline$(\mathrm{NHS}+\mathrm{VI})+\mathrm{J} 53+\mathrm{IR} \_3$ & 82,500 & 0 & 0 & 0 \\
\hline (iNHS+GO)+J53+IR & 218,000 & 256,250 & 175,000 & $5,166,667$ \\
\hline (iNHS+GO)+J53+IR_2 & 99,000 & 137,000 & 187,000 & 350,000 \\
\hline (iNHS+GO)+J53+IR_3 & 102,000 & 132,000 & $1,658,333$ & $1,766,667$ \\
\hline$(\mathrm{iNHS}+\mathrm{IV})+\mathrm{J} 53+\mathrm{IR}$ & $6,600,000$ & $2,700,000,000$ & $2,650,000,000$ & $6,930,000$ \\
\hline (iNHS+IV)+J53+IR_2 & $6,570,000$ & $2,350,000,000$ & $2,300,000,000$ & $4,700,000$ \\
\hline (iNHS+IV)+J53+IR_3 & $6,830,000$ & $1,300,000,000$ & $1,450,000,000$ & $6,730,000$ \\
\hline (iNHS+IV)+J53+IR_4 & $1,590,000,000$ & $5,950,000,000$ & $3,750,000,000$ & $7,200,000,000$ \\
\hline (iNHS+IV)+J53+IR_5 & $1,680,000,000$ & $4,450,000,000$ & $3,850,000,000$ & $6,000,000,000$ \\
\hline (iNHS+IV)+J53+IR_6 & $2,030,000,000$ & $2,100,000,000$ & $3,500,000,000$ & $5,000,000,000$ \\
\hline$(\mathrm{iNHS}+\mathrm{V})+\mathrm{J} 53+\mathrm{IR}$ & $4,980,000,000$ & $1,430,000,000$ & $2,100,000,000$ & $2,400,000,000$ \\
\hline$(\mathrm{iNHS}+\mathrm{V})+\mathrm{J} 53+\mathrm{IR} \_2$ & $3,650,000,000$ & $1,730,000,000$ & $1,780,000,000$ & $1,000,000,000$ \\
\hline$(\mathrm{iNHS}+\mathrm{V})+\mathrm{J} 53+\mathrm{IR} \_3$ & $3,980,000,000$ & $1,700,000,000$ & $2,150,000,000$ & $1,000,000,000$ \\
\hline$(\mathrm{iNHS}+\mathrm{VI})+\mathrm{J} 53+\mathrm{IR}$ & 173,000 & $8,916,667$ & $1,683,333$ & 164,000 \\
\hline (iNHS+VI)+J53+IR_2 & $4,666,667$ & 101,250 & 110,000 & 155,000 \\
\hline (iNHS+VI)+J53+IR_3 & 71,000 & 105,000 & $1,216,667$ & 157,500 \\
\hline$(\mathrm{J} 53+\mathrm{GO})+\mathrm{NHS}$ & 10,000 & 0 & 0 & 0 \\
\hline (J53+GO)+NHS_2 & 0 & 0 & 0 & 0 \\
\hline
\end{tabular}


Table A1. Cont.

\begin{tabular}{|c|c|c|c|c|}
\hline Replicate & T0 & T15 & T30 & T60 \\
\hline (J53+GO)+NHS_3 & 0 & 0 & 0 & 0 \\
\hline$(\mathrm{J} 53+\mathrm{IV})+\mathrm{NHS}$ & $7,500,000$ & $4,200,000$ & 147,000 & 0 \\
\hline (J53+IV)+NHS_2 & $7,780,000$ & $4,730,000$ & 280,000 & 0 \\
\hline$(\mathrm{J} 53+\mathrm{IV})+\mathrm{NHS} 3$ & $7,470,000$ & $5,800,000$ & 237,000 & 0 \\
\hline$(\mathrm{J} 53+\mathrm{V})+\mathrm{NHS}$ & $2,170,000$ & 0 & 0 & 0 \\
\hline$(\mathrm{J} 53+\mathrm{V})+\mathrm{NHS} \_2$ & $2,300,000$ & 0 & 0 & 0 \\
\hline$(\mathrm{J} 53+\mathrm{V})+\mathrm{NHS} 33$ & $2,920,000$ & 0 & 0 & 0 \\
\hline$(\mathrm{J} 53+\mathrm{VI})+\mathrm{NHS}$ & 136,000 & 0 & 0 & 0 \\
\hline$(\mathrm{J} 53+\mathrm{VI})+\mathrm{NHS} 2$ & 65,000 & 0 & 0 & 0 \\
\hline$(\mathrm{J} 53+\mathrm{VI})+\mathrm{NHS} 3$ & $4,333,333$ & 0 & 0 & 0 \\
\hline$(\mathrm{J} 53+\mathrm{GO})+\mathrm{iNHS}$ & 0 & 0 & 10,000 & 20,000 \\
\hline$(\mathrm{J} 53+\mathrm{GO})+\mathrm{iNHS} \_2$ & 17,500 & 150,00 & 20,000 & $3,333,333$ \\
\hline (J53+GO)+iNHS_3 & 0 & 0 & 0 & 0 \\
\hline$(\mathrm{J} 53+\mathrm{IV})+\mathrm{iNHS}$ & $6,700,000$ & $6,380,000$ & $8,270,000$ & $6,350,000$ \\
\hline$(\mathrm{J} 53+\mathrm{IV})+\mathrm{iNHS} \_2$ & $6,420,000$ & $6,680,000$ & $8,970,000$ & $5,300,000$ \\
\hline (J53+IV)+iNHS_3 & $6,200,000$ & $6,250,000$ & $7,630,000$ & $6,580,000$ \\
\hline$(\mathrm{J} 53+\mathrm{V})+\mathrm{iNHS}$ & $3,020,000$ & $1,420,000,000$ & $1,440,000,000$ & $2,650,000,000$ \\
\hline$(\mathrm{J} 53+\mathrm{V})+\mathrm{iNHS} 2$ & $3,220,000$ & $1,450,000,000$ & $1,550,000,000$ & $270,000,000$ \\
\hline$(\mathrm{J} 53+\mathrm{V})+\mathrm{iNHS} 3$ & $2,930,000$ & $1,550,000,000$ & $1,350,000,000$ & $260,000,000$ \\
\hline (J53+VI)+iNHS & $1,708,333$ & $1,466,667$ & $1,566,667$ & 147,500 \\
\hline$(\mathrm{J} 53+\mathrm{VI})+\mathrm{iNHS} 22$ & 80,000 & 102,500 & 127,000 & 256,000 \\
\hline$(\mathrm{J} 53+\mathrm{VI})+\mathrm{iNHS} 33$ & 81,250 & 70,000 & 71,000 & \\
\hline$(\mathrm{NHS}+\mathrm{J} 53)+\mathrm{GO}$ & 0 & 0 & 0 & 0 \\
\hline (NHS+J53)+GO_2 & 0 & 0 & 0 & 0 \\
\hline (NHS+J53)+GO_3 & 0 & 0 & 0 & 0 \\
\hline$(\mathrm{NHS}+\mathrm{J} 53)+\mathrm{IV}$ & 0 & 0 & 0 & 0 \\
\hline$(\mathrm{NHS}+\mathrm{J} 53)+\mathrm{IV} \_2$ & 0 & 0 & 0 & 0 \\
\hline$(\mathrm{NHS}+\mathrm{J} 53)+\mathrm{IV} \_3$ & 0 & 0 & 0 & 0 \\
\hline$(\mathrm{NHS}+\mathrm{J} 53)+\mathrm{V}$ & $2,680,000$ & 0 & 0 & 0 \\
\hline$(\mathrm{NHS}+\mathrm{J} 53)+\mathrm{V} \_2$ & $3,250,000$ & 0 & 0 & 0 \\
\hline$(\mathrm{NHS}+\mathrm{J} 53)+\mathrm{V} \_3$ & $5,080,000$ & 0 & 0 & 0 \\
\hline$(\mathrm{NHS}+\mathrm{J} 53)+\overline{\mathrm{VI}}$ & 0 & 0 & 0 & 0 \\
\hline$(\mathrm{NHS}+\mathrm{J} 53)+\mathrm{VI} \_2$ & 0 & 0 & 0 & 0 \\
\hline (NHS+J53)+VI_3 & 0 & 0 & 0 & 0 \\
\hline (iNHS+J53)+GO & $1,400,000$ & $1,483,333$ & $1,400,000$ & $1,600,000$ \\
\hline (iNHS+J53)+GO_2 & 194,000 & 284,000 & $5,333,333$ & $8,166,667$ \\
\hline (iNHS+J53)+IV & $8,100,000$ & $1,970,000,000$ & $3,900,000,000$ & $3,700,000,000$ \\
\hline (iNHS+J53)+IV_2 & $3,630,000$ & $1,380,000,000$ & $2,750,000,000$ & $1,300,000,000$ \\
\hline (iNHS+J53)+IV_3 & $1,430,000,000$ & $1,620,000,000$ & $3,760,000,000$ & $2,400,000,000$ \\
\hline$(\mathrm{iNHS}+\mathrm{J} 53)+\mathrm{V}$ & $1,910,000,000$ & $1,970,000,000$ & $1,970,000,000$ & $1,700,000,000$ \\
\hline$(\mathrm{iNHS}+\mathrm{J} 53)+\mathrm{V} \_2$ & $1,600,000,000$ & $3,060,000,000$ & $1,750,000,000$ & $1,450,000,000$ \\
\hline$(\mathrm{iNHS}+\mathrm{J} 53)+\mathrm{V} \_3$ & $1,840,000,000$ & $2,290,000,000$ & $1,500,000,000$ & $1,200,000,000$ \\
\hline (iNHS+J53)+VI & $1,458,333$ & $1,791,667$ & & 186,250 \\
\hline (iNHS+J53)+VI_2 & 160,000 & $1,533,333$ & 400,000 & $7,333,333$ \\
\hline (iNHS+J53)+VI_3 & 98,750 & 150,000 & 235,000 & 550,000 \\
\hline
\end{tabular}




\section{Appendix B}

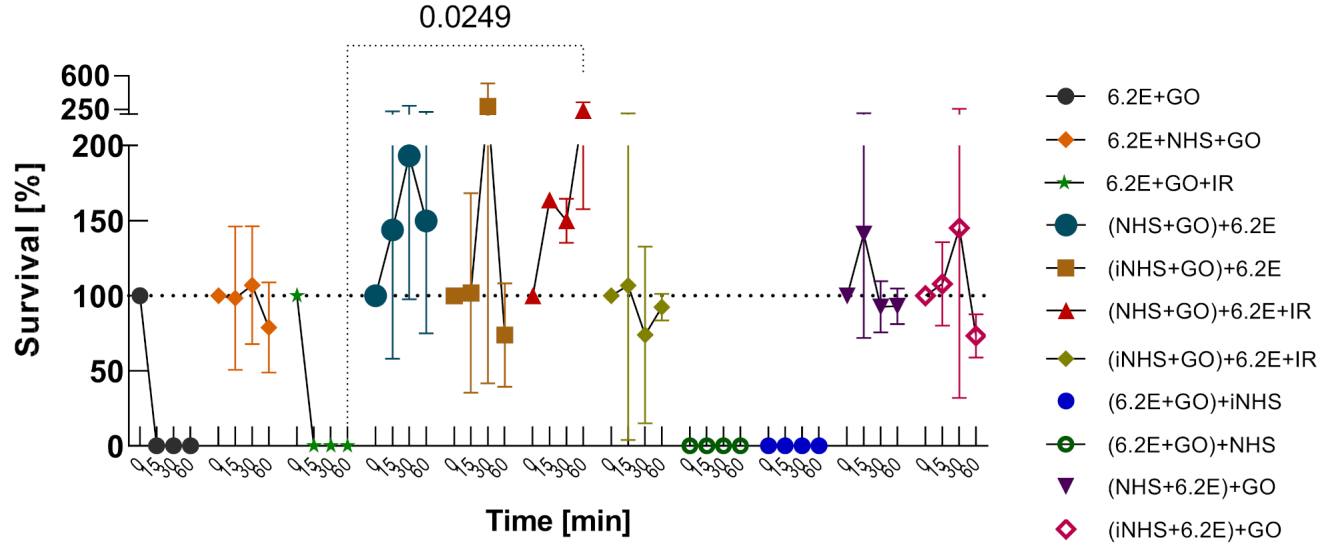

Figure A1. All types of bacterial survival experiments involving GO and E. coli 6.2E presented altogether. Graphs represent percentage of live bacteria in sample relative to average number at time zero. Standard deviation values are presented with error bars, Tukey's test $p$-values for between group T60 pairs are shown above graph when equal or lower than 0.05 . Corresponding results obtained for strain E. coli 553 are presented in Figure A9.

0.0383

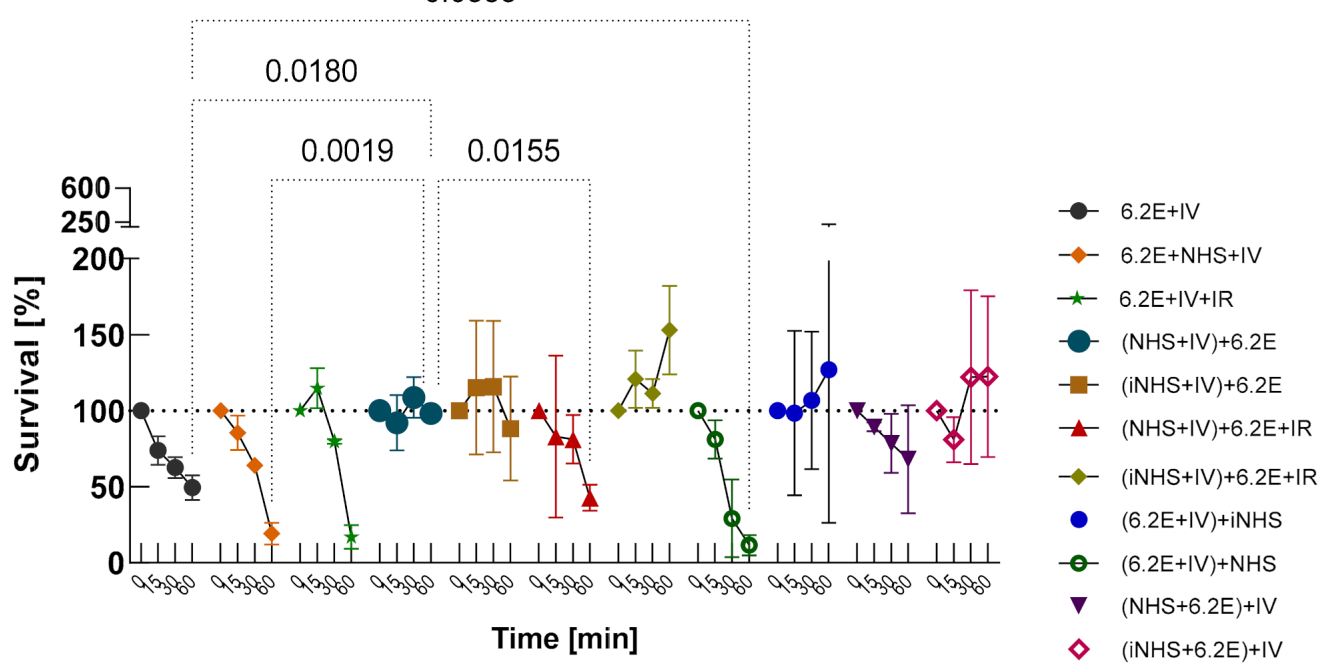

Figure A2. All types of bacterial survival experiments involving nanocomposite IV: GO-PcZr(Lys) ${ }_{2}{ }^{-}$ $\mathrm{Ag}$ and E. coli 6.2E. presented altogether. Graphs represent percentage of live bacteria in sample relative to the average number at time zero. Standard deviation values are presented with error bars, Tukey's test $p$-values for between group T60 pairs are shown above graph when equal or lower than 0.05. Corresponding results obtained for strain E. coli J53 are presented in Figure A10. 


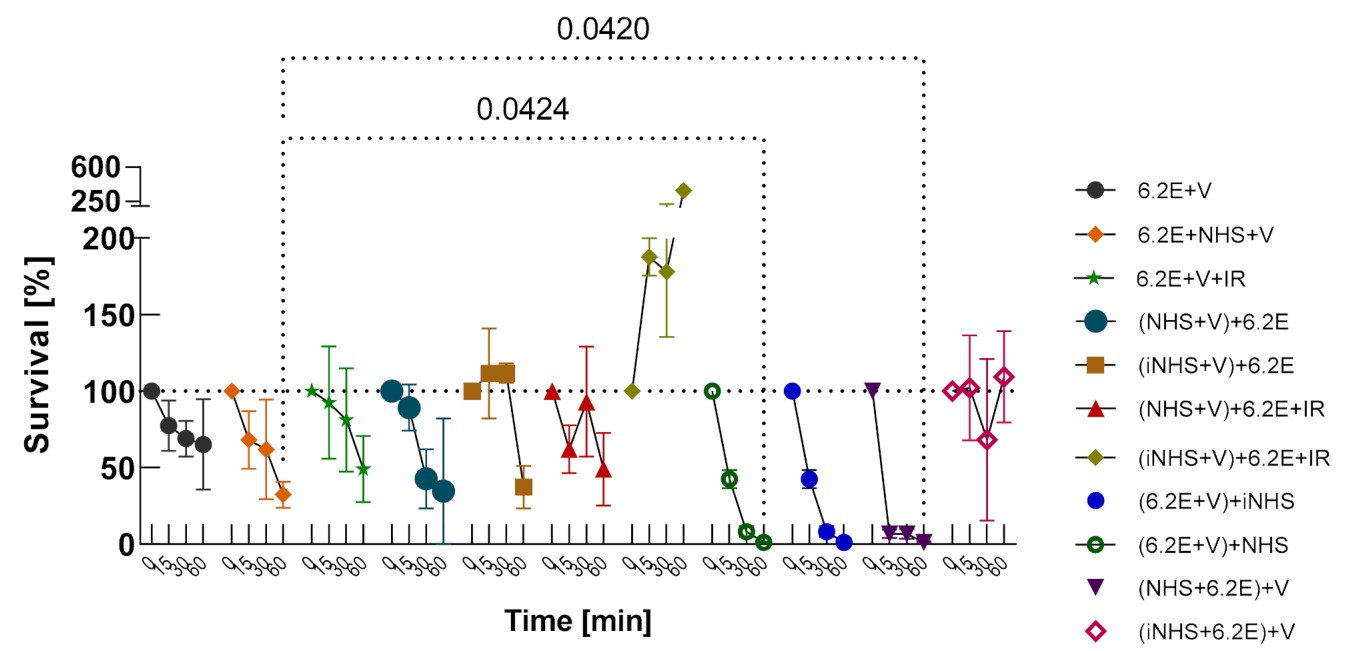

Figure A3. All types of bacterial survival experiments involving nanocomposite V: GO-Ag and E. coli 6.2E presented altogether. Graphs represent percentage of live bacteria in sample relative to average number at time zero. Standard deviation values are presented with error bars, Tukey's test $p$-values for between group T60 pairs are shown above graph when equal or lower than 0.05 . Corresponding results obtained for strain E. coli J53 are presented in Figure A11.

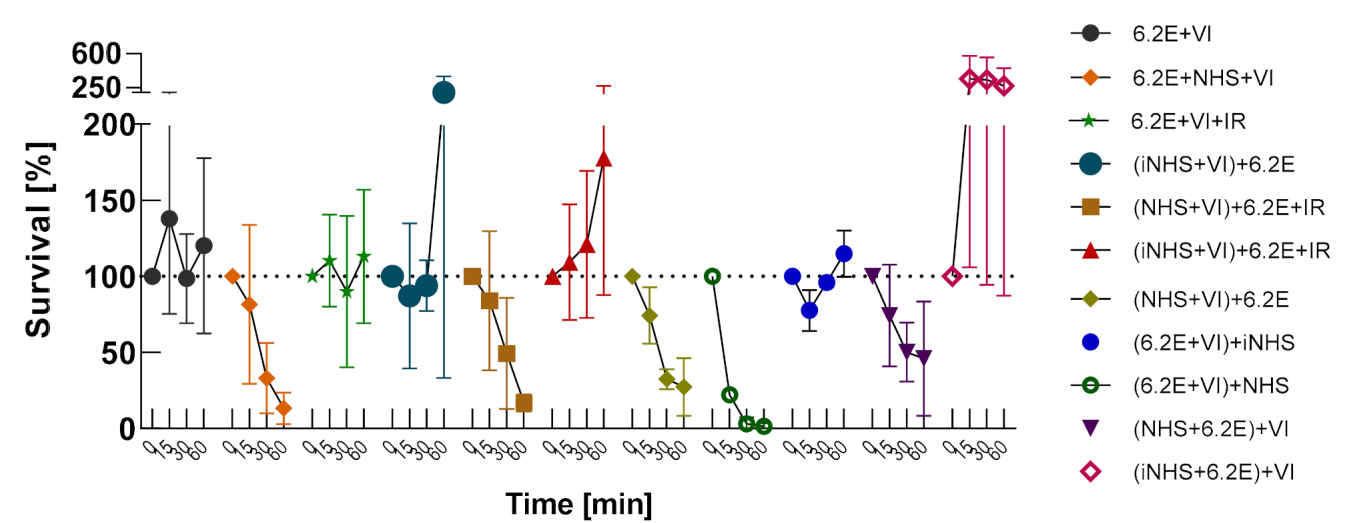

Figure A4. All types of bacterial survival experiments involving nanocomposite VI: GO-PcZr(Lys) ${ }_{2}$ and E. coli 6.2E presented altogether. Graphs represent percentage of live bacteria in sample relative to the average number at time zero. Standard deviation values are presented with error bars, Tukey's test $p$-values for between group T60 pairs are shown above graph when equal or lower than 0.05 . Corresponding results obtained for strain E. coli J53 are presented in Figure A12. 


\section{Appendix C}

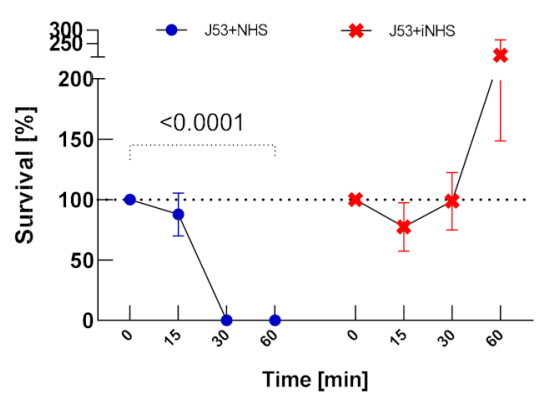

(A)

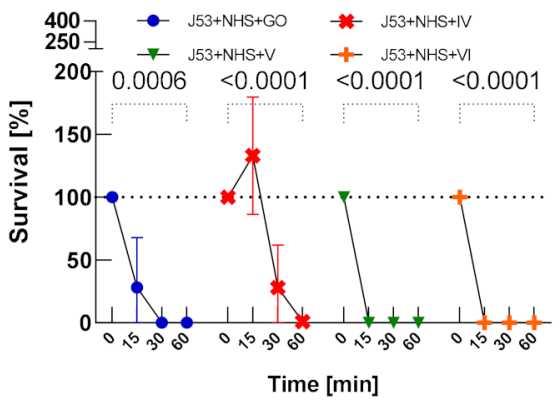

(C)

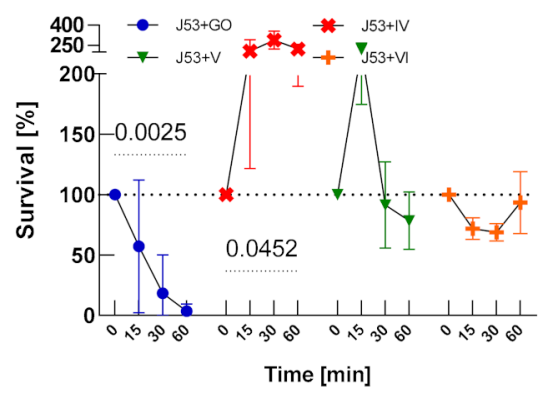

(B)

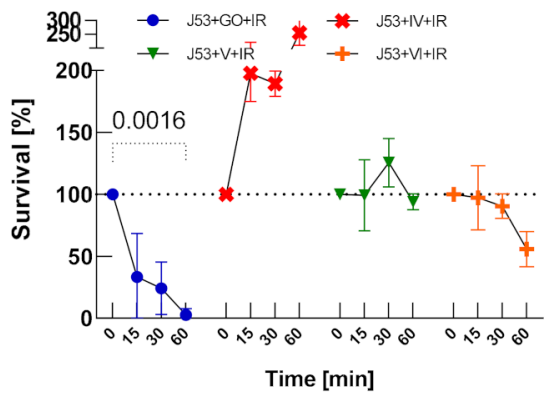

(D)

Figure A5. Bacterial survival in NHS and iNHS (A), nanocomposites GO, IV: GO-PcZr(Lys) ${ }_{2}-\mathrm{Ag}$, V: GO-Ag, VI: GO-PcZr(Lys) ${ }_{2}$ without IR irradiation (B) nanocomposites GO, IV: GO-PcZr(Lys) ${ }_{2}-\mathrm{Ag}$, V: GO-Ag, VI: GO-PcZr(Lys) 2 with IR irradiation (D) and mixed NHS with nanocomposites (C). Graphs represent percentage of live bacteria in sample relative to average number at time zero. Standard deviation values are presented with error bars, Dunnett's test $p$-values for within group T0-T60 pairs are shown above graph when equal or lower than 0.05 .

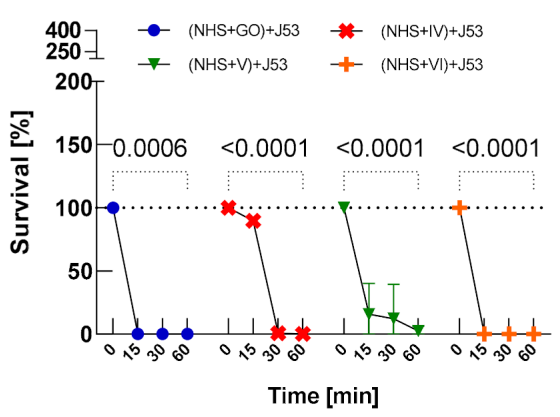

(A)

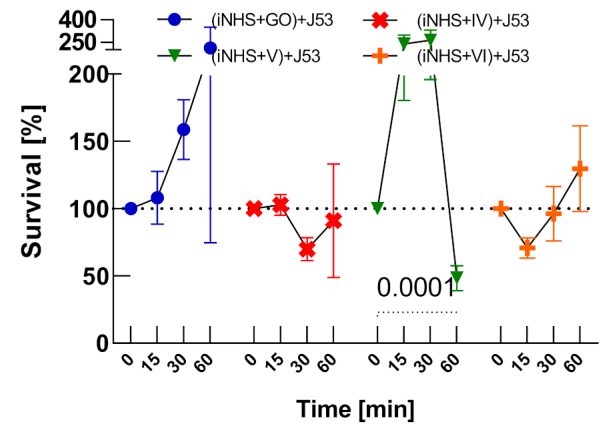

(B)

Figure A6. Cont. 


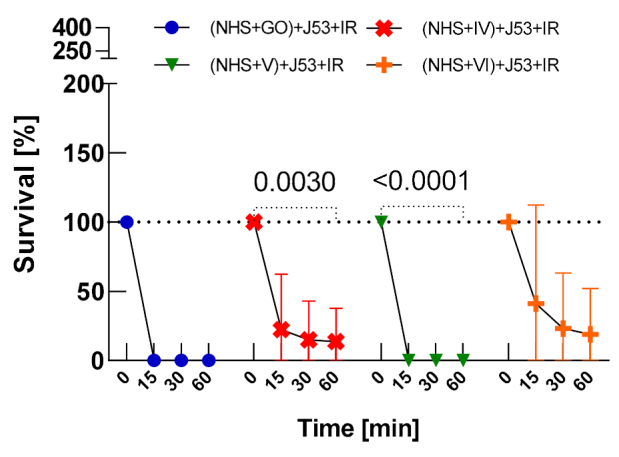

(C)

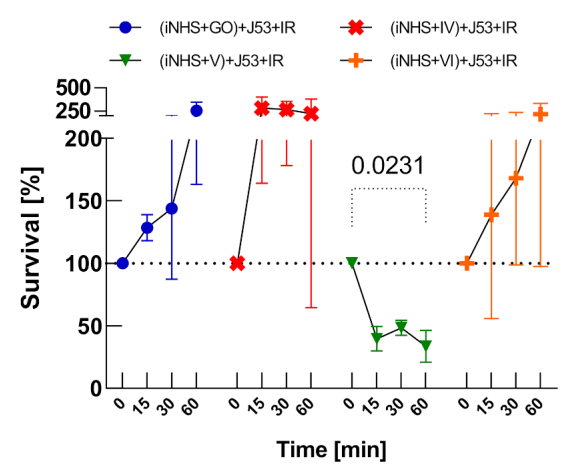

(D)

Figure A6. Bactericidal effectiveness of normal human serum exposed to nanocomposites (GO, IV: GO-PcZr(Lys) $)_{2}-\mathrm{Ag}$, V: GO-Ag, VI: GO-PcZr(Lys) 2 ) before (A) and after IR irradiation (C), the control test in iNHS (B,D). Graphs represent percentage of live bacteria in sample relative to average number at time zero. Standard deviation values are presented with error bars, Dunnett's test $p$-values for within group T0-T60 pairs are shown above graph when equal or lower than 0.05 .

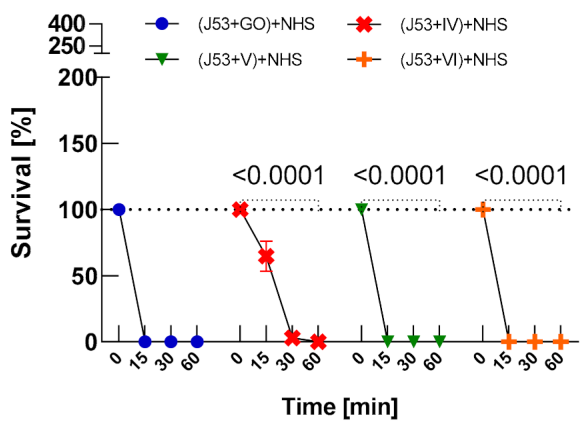

(A)

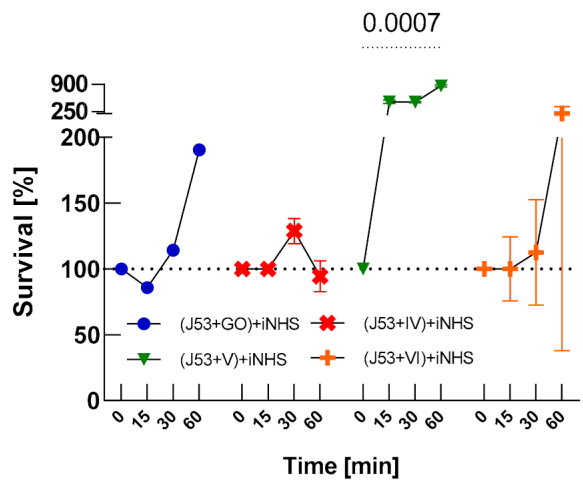

(B)

Figure A7. Serum sensitivity of bacteria exposed to nanocomposites (GO, IV: GO-PcZr(Lys) ${ }_{2}-\mathrm{Ag}$, V: GO-Ag, VI: GO-PcZr(Lys) $)_{2}$ (A) and control test in iNHS (B). Graphs represent percentage of live bacteria in the sample relative to average number at time zero. Standard deviation values are presented with error bars, Dunnett's test $p$-values for within group T0-T60 pairs are shown above graph when equal or lower than 0.05 .

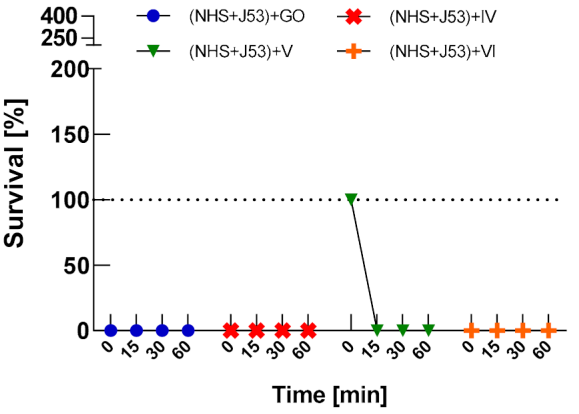

(A)

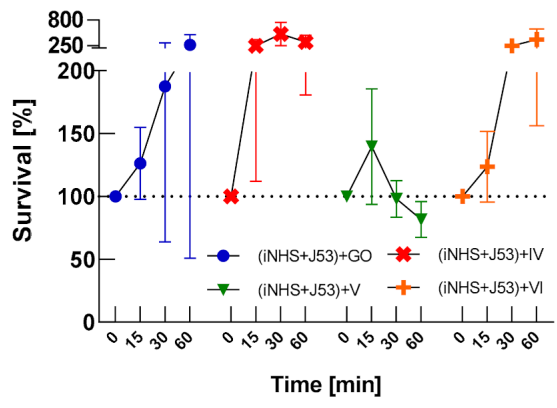

(B)

Figure A8. Sensitivity of bacteria to nanocomposites (GO, IV: GO-PcZr(Lys) $)_{2}-\mathrm{Ag}$, V: GO-Ag, VI: GO-PcZr(Lys) $)_{2}$ ) after exposure to serum (A) and control test in iNHS (B). Graphs represent percentage of live bacteria in sample relative to average number at time zero. Standard deviation values are presented with error bars, Dunnett's test $p$-values for within group T0-T60 pairs are shown above graph when equal or lower than 0.05 . 


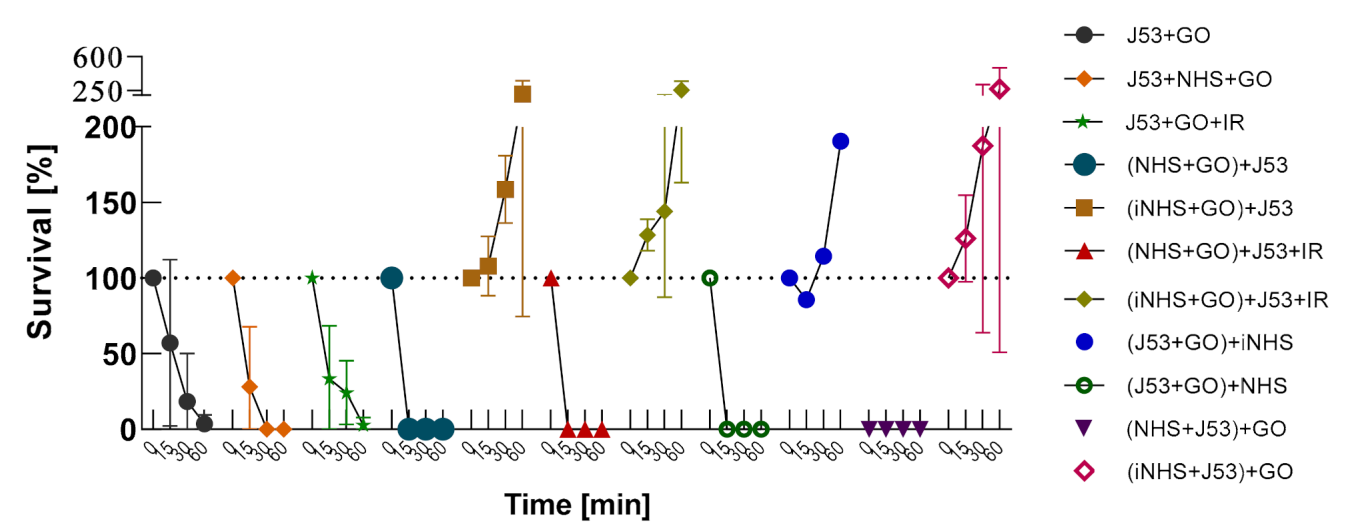

Figure A9. All types of bacterial survival experiments involving GO and E. coli J53. presented altogether. Graphs represent percentage of live bacteria in sample relative to average number at time zero. Standard deviation values are presented with error bars, Tukey's test $p$-values for between group T60 pairs are presented in Table A2.

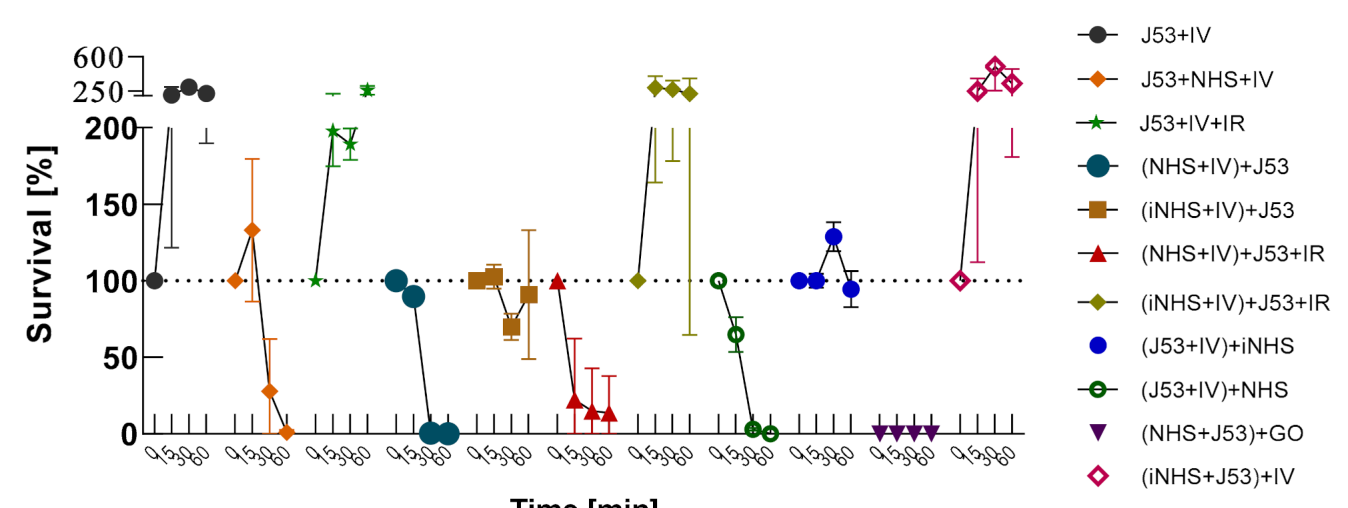

Figure A10. All types of bacterial survival experiments involving nanocomposite IV: GO-PcZr(Lys) ${ }_{2}{ }^{-}$ $\mathrm{Ag}$ and E. coli J53. presented altogether. Graphs represent percentage of live bacteria in sample relative to average number at time zero. Standard deviation values are presented with error bars, Tukey's test $p$-values for between group T60 pairs are presented in Table A2.

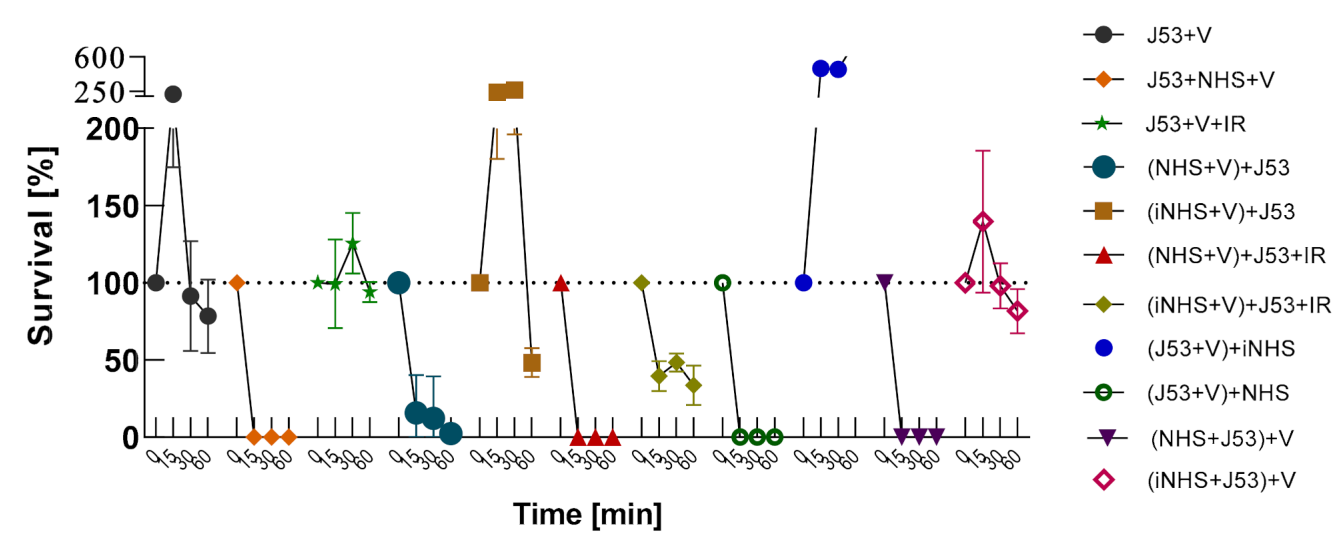

Figure A11. All types of bacterial survival experiments involving nanocomposite V: GO-Ag and E. coli J53. presented altogether. Graphs represent percentage of live bacteria in sample relative to average number at time zero. Standard deviation values are presented with error bars, Tukey's test $p$-values for between group T60 pairs are presented in Table A2. 


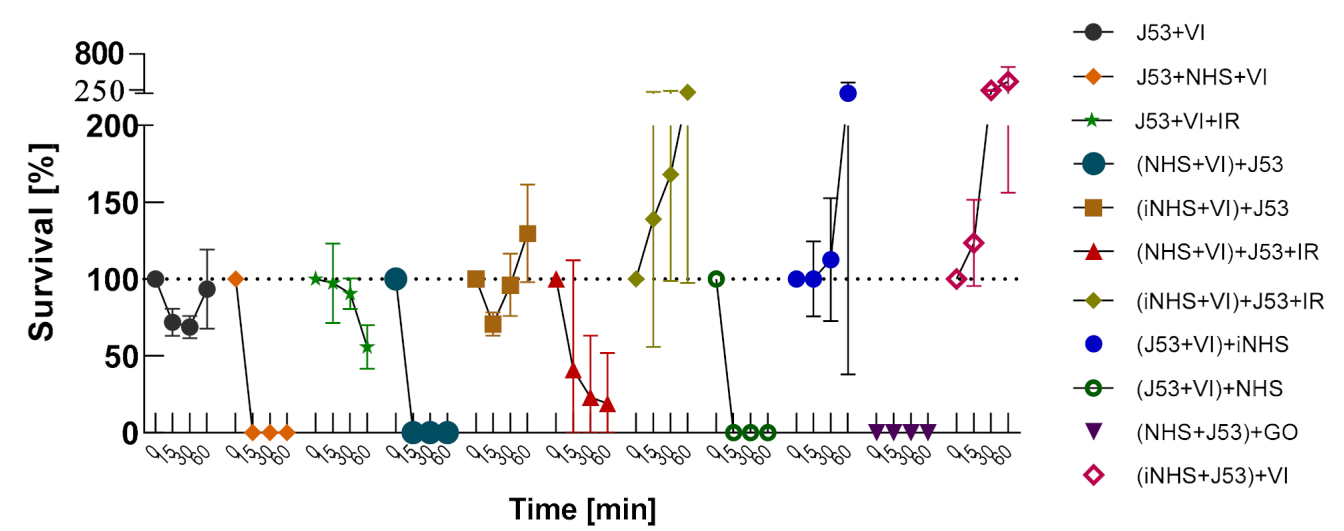

Figure A12. All types of bacterial survival experiments involving nanocomposite VI: GO-PcZr(Lys) 2 and E. coli J53. presented altogether. Graphs represent percentage of live bacteria in the sample relative to average number at time zero. Standard deviation values are presented with error bars, Tukey's test $p$-values for between group T60 pairs are presented in Table A2.

Table A2. Tukey's test $p$-values $>0.05$ for between group T60 pairs from bacterial survival experiments which results are represented in Figures A9-A12.

\begin{tabular}{ll}
\hline Experiments Comparison & $p$-Value \\
\hline J53+IV vs. J53+NHS+IV & 0.0369 \\
J53+IV vs. (NHS+IV)+J53 & 0.0367 \\
J53+IV vs. (NHS+IV)+J53+IR & 0.0141 \\
J53+IV vs. (J53+IV)+NHS & 0.0367 \\
J53+NHS+IV vs. (J53+IV)+iNHS & 0.025 \\
J53+IV+IR vs. (NHS+IV)+J53+IR & 0.033 \\
(NHS+IV)+J53 vs. (J53+IV)+iNHS & 0.0255 \\
(NHS+IV)+J53+IR vs. (J53+IV)+iNHS & 0.011 \\
(J53+IV)+NHS vs. (J53+IV)+iNHS & 0.0255 \\
J53+V vs. (J53+V)+iNHS & $<0.0001$ \\
J53+NHS+V vs. J53+V+IR & 0.0103 \\
J53+NHS+V vs. (iNHS+V)+J53 & 0.0008 \\
J53+NHS+V vs. (J53+V)+iNHS & $<0.0001$ \\
J53+V+IR vs. (NHS+V)+J53 & 0.003 \\
J53+V+IR vs. (iNHS+V)+J53 & 0.0028 \\
J53+V+IR vs. (NHS+V)+J53+IR & 0.0103 \\
J53+V+IR vs. (iNHS+V)+J53+IR & 0.0429 \\
J53+V+IR vs. (J53+V)+NHS & 0.0103 \\
J53+V+IR vs. (J53+V)+iNHS & $<0.0001$ \\
J53+V+IR vs. (NHS+J53)+V & 0.0103 \\
(NHS+V)+J53 vs. (iNHS+V)+J53 & 0.0003 \\
(NHS+V)+J53 vs. (J53+V)+iNHS & $<0.0001$ \\
(NHS+V)+J53 vs. (iNHS+J53)+V & 0.0491 \\
(iNHS+V)+J53 vs. (NHS+V)+J53+IR & 0.0008 \\
(iNHS+V)+J53 vs. (J53+V)+NHS & 0.0008 \\
(iNHS+V)+J53 vs. (J53+V)+iNHS & $<0.0001$ \\
(iNHS+V)+J53 vs. (NHS+J53)+V & 0.0008 \\
(NHS+V)+J53+IR vs. (J53+V)+iNHS & $<0.0001$ \\
(iNHS+V)+J53+IR vs. (J53+V)+iNHS & $<0.0001$ \\
(J53+V)+NHS vs. (J53+V)+iNHS & $<0.0001$ \\
(J53+V)+iNHS vs. (NHS+J53)+V & $<0.0001$ \\
(J53+V)+iNHS vs. (iNHS+J53)+V & $<0.0001$ \\
\hline
\end{tabular}




\section{Appendix D}

Table A3. Mixed-model ANOVA results for each type of bacterial survival experiment divided by bacterial strains.

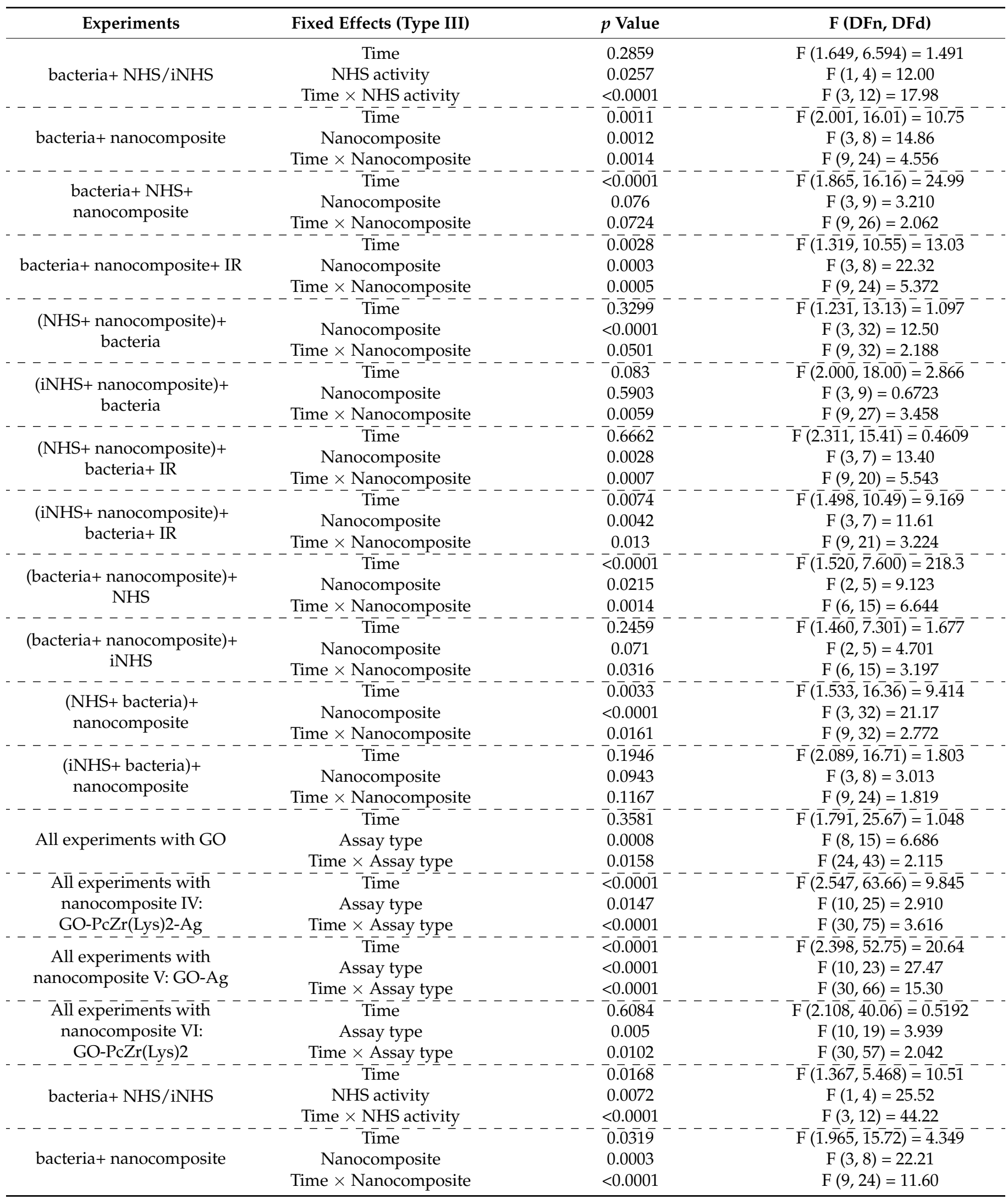


Table A3. Cont.

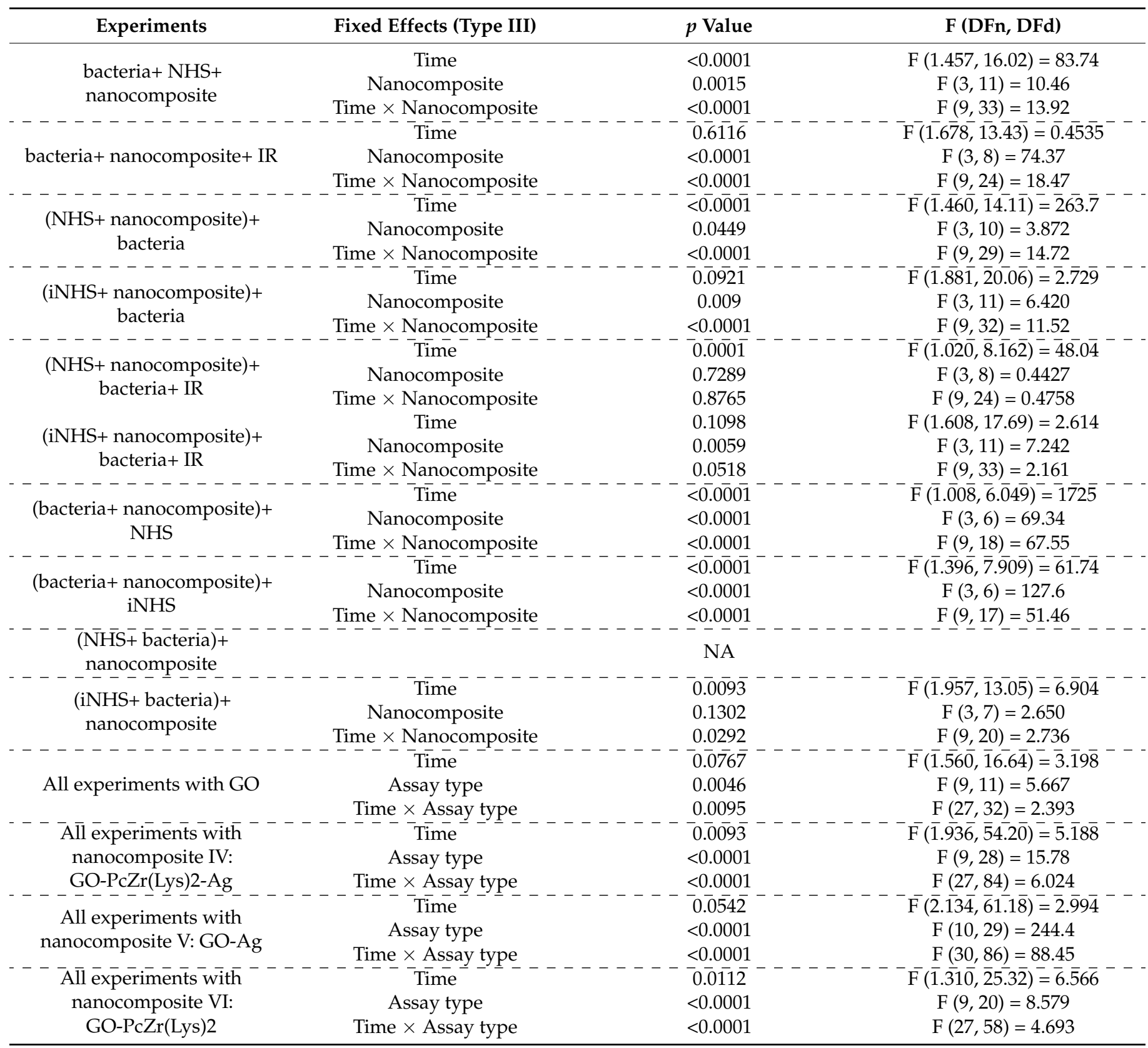

\section{Appendix E}

Table A4. Probability values of belonging to each cluster obtained by DTW/fuzzy clustering algorithms applied to all E. coli 6.2E survival time series. Cluster names were assigned based on their graphical representation (as illustrated in Figure A13).

\begin{tabular}{cccccc}
\hline Replicate & $\begin{array}{c}\text { Weak } \\
\text { Growth/Decline }\end{array}$ & Rapid Decline & Slight Decline & Growth & Moderate Decline \\
\hline 6.2E+NHS & 0.393 & 0.168 & 0.252 & 0.095 & 0.092 \\
6.2E+NHS_2 & 0.009 & 0.018 & 0.943 & 0.004 & 0.026 \\
6.2E+NHS_3 & 0.422 & 0.215 & 0.224 & 0.068 & 0.071 \\
6.2E+iNHS & 0.154 & 0.033 & 0.075 & 0.708 & 0.031 \\
6.2E+iNHS_2 & 0.179 & 0.111 & 0.189 & 0.400 & 0.121 \\
6.2E+iNHS_3 & 0.183 & 0.102 & 0.147 & 0.408 & 0.120 \\
6.2E+GO & 0.042 & 0.701 & 0.013 & 0.097 \\
\hline
\end{tabular}


Table A4. Cont.

\begin{tabular}{|c|c|c|c|c|c|}
\hline Replicate & $\begin{array}{c}\text { Weak } \\
\text { Growth/Decline }\end{array}$ & Rapid Decline & Slight Decline & Growth & Moderate Decline \\
\hline 6.2E+GO_2 & 0.042 & 0.701 & 0.147 & 0.013 & 0.097 \\
\hline 6.2E+GO_3 & 0.042 & 0.701 & 0.147 & 0.013 & 0.097 \\
\hline $6.2 \mathrm{E}+\mathrm{IV}$ & 0.240 & 0.078 & 0.338 & 0.033 & 0.311 \\
\hline $6.2 \mathrm{E}+\mathrm{IV} \_2$ & 0.201 & 0.081 & 0.519 & 0.073 & 0.126 \\
\hline 6.2E+IV_3 & 0.362 & 0.114 & 0.282 & 0.047 & 0.196 \\
\hline $6.2 \mathrm{E}+\mathrm{V}$ & 0.181 & 0.077 & 0.465 & 0.035 & 0.242 \\
\hline $6.2 \mathrm{E}+\mathrm{V} \_2$ & 0.325 & 0.113 & 0.313 & 0.064 & 0.185 \\
\hline $6.2 \mathrm{E}+\mathrm{V} \_3$ & 0.163 & 0.055 & 0.174 & 0.554 & 0.055 \\
\hline $6.2 \mathrm{E}+\mathrm{VI}$ & 0.224 & 0.090 & 0.183 & 0.402 & 0.101 \\
\hline 6.2E+VI_2 & 0.275 & 0.080 & 0.133 & 0.436 & 0.076 \\
\hline 6.2E+VI_3 & 0.253 & 0.079 & 0.350 & 0.198 & 0.120 \\
\hline $6.2 \mathrm{E}+\mathrm{NHS}+\mathrm{GO}$ & 0.225 & 0.031 & 0.064 & 0.652 & 0.029 \\
\hline $6.2 \mathrm{E}+\mathrm{NHS}+\mathrm{GO} \_2$ & 0.314 & 0.100 & 0.271 & 0.101 & 0.215 \\
\hline $6.2 \mathrm{E}+\mathrm{NHS}+\mathrm{GO} \_3$ & 0.575 & 0.052 & 0.199 & 0.081 & 0.092 \\
\hline $6.2 \mathrm{E}+\mathrm{NHS}+\mathrm{IV}$ & 0.040 & 0.051 & 0.783 & 0.011 & 0.115 \\
\hline $6.2 \mathrm{E}+\mathrm{NHS}+\mathrm{IV} \_2$ & 0.024 & 0.037 & 0.863 & 0.008 & 0.069 \\
\hline $6.2 \mathrm{E}+\mathrm{NHS}+\mathrm{IV} \_3$ & 0.048 & 0.169 & 0.378 & 0.015 & 0.390 \\
\hline $6.2 \mathrm{E}+\mathrm{NHS}+\overline{\mathrm{V}}$ & 0.113 & 0.214 & 0.320 & 0.012 & 0.341 \\
\hline 6.2E+NHS+V_2 & 0.082 & 0.143 & 0.544 & 0.015 & 0.217 \\
\hline 6.2E+NHS+V_3 & 0.435 & 0.188 & 0.236 & 0.067 & 0.075 \\
\hline $6.2 \mathrm{E}+\mathrm{NHS}+\mathrm{V} \_4$ & 0.336 & 0.067 & 0.239 & 0.033 & 0.325 \\
\hline $6.2 \mathrm{E}+\mathrm{NHS}+\overline{\mathrm{VI}}$ & 0.076 & 0.099 & 0.124 & 0.008 & 0.693 \\
\hline 6.2E+NHS+VI_2 & 0.273 & 0.168 & 0.200 & 0.036 & 0.323 \\
\hline 6.2E+NHS+VI_3 & 0.019 & 0.299 & 0.057 & 0.004 & 0.621 \\
\hline $6.2 \mathrm{E}+\mathrm{GO}+\mathrm{IR}$ & 0.042 & 0.701 & 0.147 & 0.013 & 0.097 \\
\hline $6.2 \mathrm{E}+\mathrm{GO}+\mathrm{IR} \_2$ & 0.042 & 0.701 & 0.147 & 0.013 & 0.097 \\
\hline $6.2 \mathrm{E}+\mathrm{GO}+\mathrm{IR} \_3$ & 0.042 & 0.701 & 0.147 & 0.013 & 0.097 \\
\hline $6.2 \mathrm{E}+\mathrm{IV}+\mathrm{IR}$ & 0.000 & 0.000 & 1.000 & 0.000 & 0.000 \\
\hline 6.2E+IV+IR_2 & 0.131 & 0.191 & 0.490 & 0.047 & 0.141 \\
\hline $6.2 \mathrm{E}+\mathrm{IV}+\mathrm{IR} \_3$ & 0.104 & 0.125 & 0.665 & 0.031 & 0.076 \\
\hline $6.2 \mathrm{E}+\mathrm{V}+\mathrm{IR}$ & 0.590 & 0.036 & 0.099 & 0.231 & 0.044 \\
\hline $6.2 \mathrm{E}+\mathrm{V}+\mathrm{IR} \_2$ & 0.224 & 0.068 & 0.277 & 0.026 & 0.405 \\
\hline $6.2 \mathrm{E}+\mathrm{V}+\mathrm{IR} \_3$ & 0.172 & 0.139 & 0.433 & 0.036 & 0.220 \\
\hline $6.2 \mathrm{E}+\mathrm{VI}+\mathrm{IR}$ & 0.518 & 0.071 & 0.126 & 0.187 & 0.097 \\
\hline 6.2E+VI+IR_2 & 0.173 & 0.069 & 0.155 & 0.511 & 0.091 \\
\hline $6.2 \mathrm{E}+\mathrm{VI}+\mathrm{IR} \_3$ & 0.218 & 0.132 & 0.176 & 0.309 & 0.165 \\
\hline$(\mathrm{NHS}+\mathrm{GO})+6.2 \mathrm{E}$ & 0.261 & 0.050 & 0.095 & 0.546 & 0.047 \\
\hline$(\mathrm{NHS}+\mathrm{GO})+6.2 \mathrm{E} \_2$ & 0.262 & 0.119 & 0.168 & 0.336 & 0.115 \\
\hline$(\mathrm{NHS}+\mathrm{GO})+6.2 \mathrm{E} \_3$ & 0.294 & 0.132 & 0.198 & 0.235 & 0.141 \\
\hline$(\mathrm{NHS}+\mathrm{IV})+6.2 \mathrm{E}$ & 0.329 & 0.039 & 0.110 & 0.467 & 0.056 \\
\hline (NHS+IV)+6.2E_2 & 0.008 & 0.001 & 0.003 & 0.987 & 0.001 \\
\hline$(\mathrm{NHS}+\mathrm{IV})+6.2 \mathrm{E} \_3$ & 0.061 & 0.010 & 0.031 & 0.888 & 0.009 \\
\hline$(\mathrm{NHS}+\mathrm{V})+6.2 \mathrm{E}$ & 0.000 & 1.000 & 0.000 & 0.000 & 0.000 \\
\hline$(\mathrm{NHS}+\mathrm{V})+6.2 \mathrm{E} \_2$ & 0.095 & 0.080 & 0.625 & 0.025 & 0.175 \\
\hline$(\mathrm{NHS}+\mathrm{V})+6.2 \mathrm{E} \_3$ & 0.364 & 0.183 & 0.226 & 0.090 & 0.137 \\
\hline$(\mathrm{NHS}+\mathrm{VI})+6.2 \mathrm{E}$ & 0.026 & 0.388 & 0.518 & 0.007 & 0.060 \\
\hline$(\mathrm{NHS}+\mathrm{VI})+6.2 \mathrm{E} \_2$ & 0.331 & 0.127 & 0.283 & 0.024 & 0.236 \\
\hline$(\mathrm{NHS}+\mathrm{VI})+6.2 \mathrm{E} \_3$ & 0.049 & 0.389 & 0.404 & 0.012 & 0.146 \\
\hline$(\mathrm{iNHS}+\mathrm{GO})+6.2 \mathrm{E}$ & 0.512 & 0.082 & 0.177 & 0.106 & 0.124 \\
\hline (iNHS+GO)+6.2E_2 & 0.258 & 0.138 & 0.183 & 0.288 & 0.134 \\
\hline$(\mathrm{iNHS}+\mathrm{IV})+6.2 \mathrm{E}$ & 0.291 & 0.041 & 0.109 & 0.517 & 0.042 \\
\hline$(\mathrm{iNHS}+\mathrm{IV})+6.2 \mathrm{E} \_2$ & 0.275 & 0.086 & 0.387 & 0.143 & 0.109 \\
\hline$($ iNHS+IV)+6.2E_3 & 0.398 & 0.076 & 0.161 & 0.277 & 0.087 \\
\hline$(\mathrm{iNHS}+\mathrm{IV})+6.2 \mathrm{E} \_4$ & 0.275 & 0.087 & 0.141 & 0.414 & 0.083 \\
\hline$(\mathrm{iNHS}+\mathrm{IV})+6.2 \mathrm{E} \_5$ & 0.385 & 0.024 & 0.079 & 0.486 & 0.027 \\
\hline$($ iNHS+IV)+6.2E_6 & 0.541 & 0.064 & 0.107 & 0.039 & 0.249 \\
\hline$(\mathrm{iNHS}+\mathrm{V})+6.2 \mathrm{E}$ & 1.000 & 0.000 & 0.000 & 0.000 & 0.000 \\
\hline
\end{tabular}


Table A4. Cont.

\begin{tabular}{|c|c|c|c|c|c|}
\hline Replicate & $\begin{array}{c}\text { Weak } \\
\text { Growth/Decline }\end{array}$ & Rapid Decline & Slight Decline & Growth & Moderate Decline \\
\hline$(\mathrm{iNHS}+\mathrm{V})+6.2 \mathrm{E} \_2$ & 0.456 & 0.172 & 0.222 & 0.066 & 0.084 \\
\hline$(\mathrm{iNHS}+\mathrm{V})+6.2 \mathrm{E} \_3$ & 0.379 & 0.166 & 0.254 & 0.105 & 0.096 \\
\hline$(\mathrm{iNHS}+\mathrm{VI})+6.2 \mathrm{E}$ & 0.273 & 0.078 & 0.255 & 0.200 & 0.194 \\
\hline (iNHS+VI)+6.2E_2 & 0.238 & 0.111 & 0.166 & 0.378 & 0.107 \\
\hline$(\mathrm{NHS}+\mathrm{GO})+6.2 \mathrm{E}+\mathrm{IR}$ & 0.264 & 0.115 & 0.165 & 0.345 & 0.111 \\
\hline$(\mathrm{NHS}+\mathrm{GO})+6.2 \mathrm{E}+\mathrm{IR} \_2$ & 0.273 & 0.094 & 0.148 & 0.395 & 0.090 \\
\hline$(\mathrm{NHS}+\mathrm{IV})+6.2 \mathrm{E}+\mathrm{IR}$ & 0.127 & 0.132 & 0.486 & 0.041 & 0.215 \\
\hline$(\mathrm{NHS}+\mathrm{IV})+6.2 \mathrm{E}+\mathrm{IR} \_2$ & 0.449 & 0.100 & 0.174 & 0.128 & 0.149 \\
\hline$(\mathrm{NHS}+\mathrm{IV})+6.2 \mathrm{E}+\mathrm{IR} \_3$ & 0.297 & 0.086 & 0.189 & 0.027 & 0.402 \\
\hline$(\mathrm{NHS}+\mathrm{V})+6.2 \mathrm{E}+\mathrm{IR}$ & 0.290 & 0.100 & 0.116 & 0.018 & 0.477 \\
\hline$(\mathrm{NHS}+\mathrm{V})+6.2 \mathrm{E}+\mathrm{IR} \_2$ & 0.480 & 0.128 & 0.262 & 0.063 & 0.066 \\
\hline$(\mathrm{NHS}+\mathrm{V})+6.2 \mathrm{E}+\mathrm{IR} \_3$ & 0.338 & 0.063 & 0.179 & 0.319 & 0.102 \\
\hline$(\mathrm{NHS}+\mathrm{VI})+6.2 \mathrm{E}+\mathrm{IR}$ & 0.226 & 0.341 & 0.254 & 0.025 & 0.153 \\
\hline$(\mathrm{NHS}+\mathrm{VI})+6.2 \mathrm{E}+\mathrm{IR} \_2$ & 0.056 & 0.188 & 0.704 & 0.021 & 0.031 \\
\hline$(\mathrm{NHS}+\mathrm{VI})+6.2 \mathrm{E}+\mathrm{IR} \_3$ & 0.036 & 0.549 & 0.234 & 0.007 & 0.174 \\
\hline$(\mathrm{iNHS}+\mathrm{GO})+6.2 \mathrm{E}+\mathrm{IR}$ & 0.248 & 0.243 & 0.215 & 0.124 & 0.170 \\
\hline$(\mathrm{iNHS}+\mathrm{GO})+6.2 \mathrm{E}+\mathrm{IR} \_2$ & 0.352 & 0.066 & 0.138 & 0.377 & 0.067 \\
\hline$(\mathrm{iNHS}+\mathrm{IV})+6.2 \mathrm{E}+\mathrm{IR}$ & 0.185 & 0.066 & 0.129 & 0.558 & 0.062 \\
\hline$(\mathrm{iNHS}+\mathrm{IV})+6.2 \mathrm{E}+\mathrm{IR} \_2$ & 0.230 & 0.044 & 0.087 & 0.598 & 0.041 \\
\hline$(\mathrm{iNHS}+\mathrm{IV})+6.2 \mathrm{E}+\mathrm{IR} \_3$ & 0.230 & 0.032 & 0.067 & 0.641 & 0.030 \\
\hline$(\mathrm{iNHS}+\mathrm{V})+6.2 \mathrm{E}+\mathrm{IR}$ & 0.260 & 0.123 & 0.171 & 0.328 & 0.119 \\
\hline$(\mathrm{iNHS}+\mathrm{V})+6.2 \mathrm{E}+\mathrm{IR} \_2$ & 0.252 & 0.135 & 0.179 & 0.303 & 0.131 \\
\hline$(\mathrm{iNHS}+\mathrm{V})+6.2 \mathrm{E}+\mathrm{IR} \_3$ & 0.243 & 0.148 & 0.185 & 0.280 & 0.144 \\
\hline (iNHS+VI)+6.2E+IR & 0.274 & 0.090 & 0.143 & 0.408 & 0.085 \\
\hline$(\mathrm{iNHS}+\mathrm{VI})+6.2 \mathrm{E}+\mathrm{IR} \_2$ & 0.189 & 0.128 & 0.220 & 0.297 & 0.166 \\
\hline$(\mathrm{iNHS}+\mathrm{VI})+6.2 \mathrm{E}+\mathrm{IR} \_3$ & 0.215 & 0.024 & 0.069 & 0.669 & 0.023 \\
\hline$(6.2 \mathrm{E}+\mathrm{GO})+\mathrm{NHS}$ & 0.000 & 1.000 & 0.000 & 0.000 & 0.000 \\
\hline$(6.2 \mathrm{E}+\mathrm{IV})+\mathrm{NHS}$ & 0.034 & 0.185 & 0.265 & 0.010 & 0.506 \\
\hline$(6.2 \mathrm{E}+\mathrm{IV})+\mathrm{NHS} \_2$ & 0.016 & 0.768 & 0.175 & 0.005 & 0.036 \\
\hline$(6.2 \mathrm{E}+\mathrm{IV})+\mathrm{NHS} \_3$ & 0.066 & 0.168 & 0.281 & 0.015 & 0.470 \\
\hline$(6.2 \mathrm{E}+\mathrm{V})+\mathrm{NHS}$ & 0.021 & 0.602 & 0.060 & 0.005 & 0.312 \\
\hline$(6.2 \mathrm{E}+\mathrm{V})+\mathrm{NHS} \_2$ & 0.021 & 0.298 & 0.065 & 0.005 & 0.611 \\
\hline$(6.2 \mathrm{E}+\mathrm{V})+\mathrm{NHS} 3$ & 0.016 & 0.791 & 0.055 & 0.004 & 0.134 \\
\hline$(6.2 \mathrm{E}+\mathrm{VI})+\mathrm{NHS}$ & 0.020 & 0.785 & 0.101 & 0.005 & 0.089 \\
\hline$(6.2 \mathrm{E}+\mathrm{VI})+\mathrm{NHS} \_2$ & 0.021 & 0.822 & 0.089 & 0.006 & 0.063 \\
\hline$(6.2 \mathrm{E}+\mathrm{GO})+\mathrm{iNHS}$ & 0.000 & 1.000 & 0.000 & 0.000 & 0.000 \\
\hline$(6.2 \mathrm{E}+\mathrm{IV})+\mathrm{iNHS}$ & 0.000 & 0.000 & 0.000 & 0.000 & 1.000 \\
\hline$(6.2 \mathrm{E}+\mathrm{IV})+\mathrm{iNHS} \_2$ & 0.262 & 0.078 & 0.131 & 0.449 & 0.080 \\
\hline$(6.2 \mathrm{E}+\mathrm{IV})+\mathrm{iNHS} \_3$ & 0.275 & 0.083 & 0.136 & 0.426 & 0.079 \\
\hline$(6.2 \mathrm{E}+\mathrm{V})+\mathrm{iNHS}$ & 0.021 & 0.602 & 0.060 & 0.005 & 0.312 \\
\hline$(6.2 \mathrm{E}+\mathrm{V})+\mathrm{iNHS} \_2$ & 0.021 & 0.298 & 0.065 & 0.005 & 0.611 \\
\hline$(6.2 \mathrm{E}+\mathrm{V})+\mathrm{iNHS} 33$ & 0.043 & 0.380 & 0.048 & 0.007 & 0.522 \\
\hline$(6.2 \mathrm{E}+\mathrm{VI})+\mathrm{iNHS}$ & 0.185 & 0.051 & 0.132 & 0.557 & 0.076 \\
\hline$(6.2 \mathrm{E}+\mathrm{VI})+\mathrm{iNHS} 22$ & 0.100 & 0.020 & 0.052 & 0.807 & 0.020 \\
\hline$(\mathrm{NHS}+6.2 \mathrm{E})+\mathrm{GO}$ & 0.000 & 0.000 & 0.000 & 1.000 & 0.000 \\
\hline$(\mathrm{NHS}+6.2 \mathrm{E})+\mathrm{GO} \_2$ & 0.281 & 0.115 & 0.219 & 0.253 & 0.132 \\
\hline$(\mathrm{NHS}+6.2 \mathrm{E})+\mathrm{GO} \_3$ & 0.153 & 0.026 & 0.085 & 0.713 & 0.023 \\
\hline$(\mathrm{NHS}+6.2 \mathrm{E})+\mathrm{IV}$ & 0.150 & 0.126 & 0.547 & 0.036 & 0.141 \\
\hline$(\mathrm{NHS}+6.2 \mathrm{E})+\mathrm{IV} \_2$ & 0.299 & 0.111 & 0.332 & 0.109 & 0.149 \\
\hline$(\mathrm{NHS}+6.2 \mathrm{E})+\mathrm{IV} \_3$ & 0.037 & 0.007 & 0.017 & 0.930 & 0.007 \\
\hline$(\mathrm{NHS}+6.2 \mathrm{E})+\mathrm{V}$ & 0.045 & 0.621 & 0.202 & 0.013 & 0.119 \\
\hline$(\mathrm{NHS}+6.2 \mathrm{E})+\mathrm{V} \_2$ & 0.042 & 0.678 & 0.165 & 0.012 & 0.103 \\
\hline$(\mathrm{NHS}+6.2 \mathrm{E})+\mathrm{V} \_3$ & 0.041 & 0.685 & 0.160 & 0.013 & 0.101 \\
\hline$(\mathrm{NHS}+6.2 \mathrm{E})+\mathrm{VI}$ & 0.085 & 0.067 & 0.765 & 0.020 & 0.064 \\
\hline$(\mathrm{NHS}+6.2 \mathrm{E})+\mathrm{VI} 22$ & 0.364 & 0.144 & 0.169 & 0.107 & 0.217 \\
\hline$(\mathrm{NHS}+6.2 \mathrm{E})+\mathrm{VI} 33$ & 0.083 & 0.148 & 0.433 & 0.012 & 0.323 \\
\hline$(\mathrm{iNHS}+6.2 \mathrm{E})+\mathrm{GO}$ & 0.291 & 0.104 & 0.357 & 0.091 & 0.156 \\
\hline
\end{tabular}


Table A4. Cont.

\begin{tabular}{cccccc}
\hline Replicate & $\begin{array}{c}\text { Weak } \\
\text { Growth/Decline }\end{array}$ & Rapid Decline & Slight Decline & Growth & Moderate Decline \\
\hline (iNHS+6.2E)+GO_2 & 0.324 & 0.077 & 0.188 & 0.337 & 0.075 \\
(iNHS+6.2E)+GO_3 & 0.297 & 0.108 & 0.182 & 0.303 & 0.110 \\
(iNHS+6.2E)+IV & 0.416 & 0.085 & 0.191 & 0.458 & 0.244 \\
(iNHS+6.2E)+IV_2 & 0.266 & 0.078 & 0.125 & 0.511 & 0.074 \\
(iNHS+6.2E)+IV_3 & 0.254 & 0.062 & 0.110 & 0.575 & 0.063 \\
(iNHS+6.2E)+V & 0.254 & 0.044 & 0.086 & 0.049 & 0.208 \\
(iNHS+6.2E)+V_2 & 0.221 & 0.135 & 0.346 & 0.234 & 0.088 \\
(iNHS+6.2E)+V_3 & 0.257 & 0.056 & 0.107 & 0.285 & 0.174 \\
(iNHS+6.2E)+VI & 0.221 & 0.176 & 0.184 & 0.426 & 0.141 \\
(iNHS+6.2E)+VI_2 & 0.245 & 0.145 & 0.155 & & 0.099 \\
(iNHS+6.2E)+VI_3 & 0.222 & 0.099 & & & \\
\hline
\end{tabular}
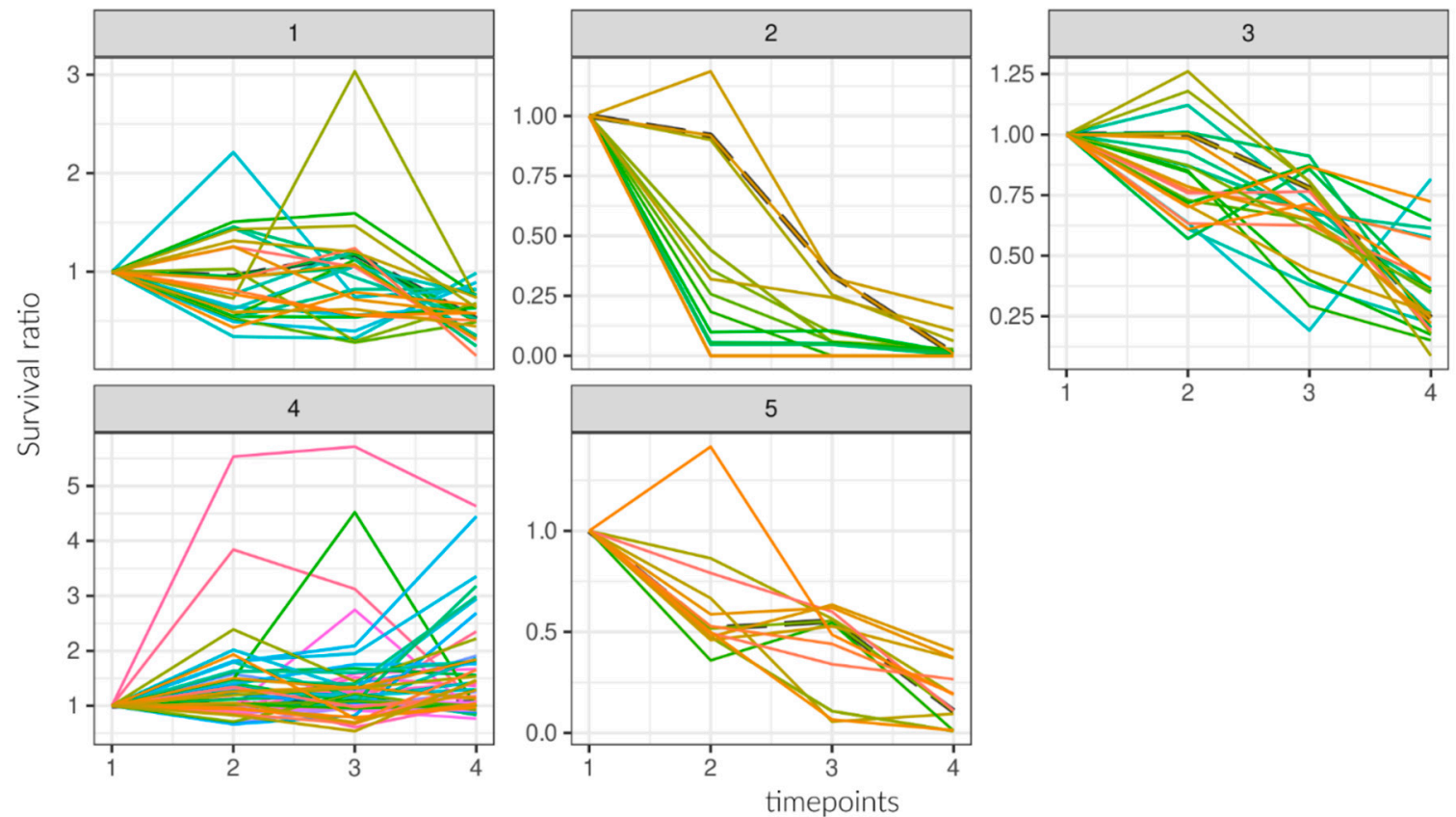

Figure A13. Escherichia coli 6.2E survival experiments results represented as graphs and divided into 5 clusters using DTW / fuzzy clustering algorithms. Cluster 1 was named as 'Weak growth/decline', cluster 2 as 'Rapid decline', cluster 3 as 'Slight decline', cluster 4 as 'Growth' and cluster 5 as 'Moderate decline'. Each line represents one experiment replicate. Dashed line is the centroid of cluster.

\section{References}

1. Lukowiak, A.; Kedziora, A.; Strek, W. Antimicrobial Graphene Family Materials: Progress, Advances, Hopes and Fears. Adv. Colloid Interface Sci. 2016, 236, 101-112. [CrossRef] [PubMed]

2. Chung, C.; Kim, Y.-K.; Shin, D.; Ryoo, S.-R.; Hong, B.H.; Min, D.-H. Biomedical Applications of Graphene and Graphene Oxide. Acc. Chem. Res. 2013, 46, 2211-2224. [CrossRef] [PubMed]

3. Goenka, S.; Sant, V.; Sant, S. Graphene-Based Nanomaterials for Drug Delivery and Tissue Engineering. J. Control. Release 2014, 173, 75-88. [CrossRef] [PubMed]

4. Kumar, Y.R.; Deshmukh, K.; Sadasivuni, K.K.; Pasha, S.K.K. Graphene Quantum Dot Based Materials for Sensing, Bio-Imaging and Energy Storage Applications: A Review. RSC Adv. 2020, 10, 23861-23898. [CrossRef]

5. Tajik, S.; Dourandish, Z.; Zhang, K.; Beitollahi, H.; Le, Q.V.; Jang, H.W.; Shokouhimehr, M. Carbon and Graphene Quantum Dots: A Review on Syntheses, Characterization, Biological and Sensing Applications for Neurotransmitter Determination. RSC Adv. 2020, 10, 15406-15429. [CrossRef] 
6. Saladino, M.L.; Markowska, M.; Carmone, C.; Cancemi, P.; Alduina, R.; Presentato, A.; Scaffaro, R.; Biały, D.; Hasiak, M.; Hreniak, D.; et al. Graphene Oxide Carboxymethylcellulose Nanocomposite for Dressing Materials. Materials 2020, 13, 1980. [CrossRef] [PubMed]

7. Vijay Kumar, S.; Huang, N.M.; Lim, H.N.; Marlinda, A.R.; Harrison, I.; Chia, C.H. One-Step Size-Controlled Synthesis of Functional Graphene Oxide/silver Nanocomposites at Room Temperature. Chem. Eng. J. 2013, 219, 217-224. [CrossRef]

8. Zhang, D.; Liu, X.; Wang, X. Green Synthesis of Graphene Oxide Sheets Decorated by Silver Nanoprisms and Their Anti-Bacterial Properties. J. Inorg. Biochem. 2011, 105, 1181-1186. [CrossRef] [PubMed]

9. Kedziora, A.; Gerasymchuk, Y.; Sroka, E.; Bugla-Płoskońska, G.; Doroszkiewicz, W.; Rybak, Z.; Hreniak, D.C.; Wilgusz, R.; Strek, W.A. Use of the materials based on partially reduced graphene-oxide with silver nanoparticle as bacteriostatic and bactericidal agent. Polim. Med. 2013, 43, 129-134.

10. de Faria, A.F.; Martinez, D.S.T.; Meira, S.M.M.; de Moraes, A.C.M.; Brandelli, A.; Filho, A.G.S.; Alves, O.L. Anti-Adhesion and Antibacterial Activity of Silver Nanoparticles Supported on Graphene Oxide Sheets. Colloids Surf. B Biointerfaces 2014, 113, 115-124. [CrossRef]

11. Zhu, Z.; Su, M.; Ma, L.; Ma, L.; Liu, D.; Wang, Z. Preparation of Graphene Oxide-Silver Nanoparticle Nanohybrids with Highly Antibacterial Capability. Talanta 2013, 117, 449-455. [CrossRef]

12. Swimberghe, R.C.D.; Coenye, T.; Moor, R.J.G.D.; Meire, M.A. Biofilm Model Systems for Root Canal Disinfection: A Literature Review. Int. Endod. J. 2019, 52, 604-628. [CrossRef]

13. Sakko, M.; Tjäderhane, L.; Rautemaa-Richardson, R. Microbiology of Root Canal Infections. Prim. Dent. J. 2016, 5, 84-89. [CrossRef]

14. Szeto, G.L.; Lavik, E.B. Materials Design at the Interface of Nanoparticles and Innate Immunity. J. Mater. Chem. B 2016, 4, 1610-1618. [CrossRef]

15. Kononenko, V.; Narat, M.; Drobne, D. Nanoparticle Interaction with the Immune System/Interakcije Nanodelcev Z Imunskim Sistemom. Arch. Ind. Hyg. Toxicol. 2015, 66. [CrossRef]

16. Capriotti, A.L.; Caracciolo, G.; Caruso, G.; Cavaliere, C.; Pozzi, D.; Samperi, R.; Laganà, A. Label-Free Quantitative Analysis for Studying the Interactions between Nanoparticles and Plasma Proteins. Anal. Bioanal. Chem. 2013, 405, 635-645. [CrossRef]

17. Bugla-Płoskońska, G.; Kiersnowski, A.; Futoma-Kołoch, B.; Doroszkiewicz, W. Killing of Gram-Negative Bacteria with Normal Human Serum and Normal Bovine Serum: Use of Lysozyme and Complement Proteins in the Death of Salmonella Strains O48. Microb. Ecol. 2009, 58, 276-289. [CrossRef]

18. Liu, Y.; Li, H.; Zhang, Y.; Ye, Y.; Gao, Y.; Li, J. In Vitro and in Vivo Activity of Ciprofloxacin/fosfomycin Combination Therapy against Ciprofloxacin-Resistant Shigella Flexneri Isolates. Infect. Drug Resist. 2019, 12, 1619-1628. [CrossRef]

19. Asai, M.; Li, Y.; Khara, J.S.; Robertson, B.D.; Langford, P.R.; Newton, S.M. Galleria Mellonella: An Infection Model for Screening Compounds Against the Mycobacterium Tuberculosis Complex. Front. Microbiol. 2019, 10. [CrossRef]

20. Desbois, A.P.; Coote, P.J. Wax Moth Larva (Galleria mellonella): An in Vivo Model for Assessing the Efficacy of Antistaphylococcal Agents. J. Antimicrob. Chemother. 2011, 66, 1785-1790. [CrossRef]

21. Kay, S.; Edwards, J.; Brown, J.; Dixon, R. Galleria Mellonella Infection Model Identifies Both High and Low Lethality of Clostridium Perfringens Toxigenic Strains and Their Response to Antimicrobials. Front. Microbiol. 2019, 10. [CrossRef]

22. Harding, C.R.; Schroeder, G.N.; Reynolds, S.; Kosta, A.; Collins, J.W.; Mousnier, A.; Frankel, G. Legionella Pneumophila Pathogenesis in the Galleria Mellonella Infection Model. Infect. Immun. 2012, 80, 2780-2790. [CrossRef]

23. Alghoribi, M.F.; Gibreel, T.M.; Dodgson, A.R.; Beatson, S.A.; Upton, M. Galleria Mellonella Infection Model Demonstrates High Lethality of ST69 and ST127 Uropathogenic E. coli. PLoS ONE 2014, 9, e101547. [CrossRef]

24. Kavanagh, K.; Sheehan, G. The Use of Galleria Mellonella Larvae to Identify Novel Antimicrobial Agents against Fungal Species of Medical Interest. J. Fungi Basel Switz. 2018, 4, 113. [CrossRef]

25. Nyamu, S.N.; Ombaka, L.; Masika, E.; Ng'ang'a, M. Antimicrobial Photodynamic Activity of Phthalocyanine Derivatives. Adv. Chem. 2018, 2018, 2598062. [CrossRef]

26. Gao, Y.; Mai, B.; Wang, A.; Li, M.; Wang, X.; Zhang, K.; Liu, Q.; Wei, S.; Wang, P. Antimicrobial Properties of a New Type of Photosensitizer Derived from Phthalocyanine against Planktonic and Biofilm Forms of Staphylococcus Aureus. Photodiagnosis Photodyn. Ther. 2018, 21, 316-326. [CrossRef]

27. Mantareva, V.N.; Angelov, I.; Wöhrle, D.; Borisova, E.; Kussovski, V. Metallophthalocyanines for Antimicrobial Photodynamic Therapy: An Overview of Our Experience. J. Porphyr. Phthalocyanines 2013, 17, 399-416. [CrossRef]

28. Gerasymchuk, Y.; Łukowiak, A.; Kędziora, A.; Wedzyńska, A.; Bugla-Płoskońska, G.; Piątek, D.; Bachanek, T.; Chernii, V.; Tomachynski, L.; Stręk, W. New Antibacterial Photoactive Nanocomposite Additives for Endodontic Cements and Fillings; Di Bartolo, B., Collins, J., Silvestri, L., Eds.; Springer: Amsterdam, The Netherlands, 2017; pp. 507-509.

29. Gerasymchuk, Y.; Lukowiak, A.; Wedzynska, A.; Kedziora, A.; Bugla-Ploskonska, G.; Piatek, D.; Bachanek, T.; Chernii, V.; Tomachynski, L.; Strek, W. New Photosensitive Nanometric Graphite Oxide Composites as Antimicrobial Material with Prolonged Action. J. Inorg. Biochem. 2016, 159, 142-148. [CrossRef]

30. Husain, M.; Wu, D.; Saber, A.T.; Decan, N.; Jacobsen, N.R.; Williams, A.; Yauk, C.L.; Wallin, H.; Vogel, U.; Halappanavar, S. Intratracheally Instilled Titanium Dioxide Nanoparticles Translocate to Heart and Liver and Activate Complement Cascade in the Heart of C57BL/ 6 Mice. Nanotoxicology 2015, 9, 1013-1022. [CrossRef] 
31. Yu, K.; Lai, B.F.L.; Foley, J.H.; Krisinger, M.J.; Conway, E.M.; Kizhakkedathu, J.N. Modulation of Complement Activation and Amplification on Nanoparticle Surfaces by Glycopolymer Conformation and Chemistry. ACS Nano 2014, 8, 7687-7703. [CrossRef]

32. Kaiser, J.-P.; Roesslein, M.; Diener, L.; Wick, P. Human Health Risk of Ingested Nanoparticles That Are Added as Multifunctional Agents to Paints: An In Vitro Study. PLoS ONE 2013, 8, e83215. [CrossRef] [PubMed]

33. Huang, H.; Lai, W.; Cui, M.; Liang, L.; Lin, Y.; Fang, Q.; Liu, Y.; Xie, L. An Evaluation of Blood Compatibility of Silver Nanoparticles. Sci. Rep. 2016, 6, 1-15. [CrossRef] [PubMed]

34. Sladowski, D.; Wasiutyński, A.; Wilczyński, G.; Grabska-Liberek, I.; Coecke, S.; Kinsner, A.; Kochanowska, I. Expression of the Membrane Complement Regulatory Proteins (CD55 and CD59) in Human Thymus. Folia Histochem. Cytobiol. 2006, 44, $263-267$. [PubMed]

35. Moghimi, S.M.; Simberg, D. Complement Activation Turnover on Surfaces of Nanoparticles. Nano Today 2017, 15, 8-10. [CrossRef]

36. Fornaguera, C.; Calderó, G.; Mitjans, M.; Vinardell, M.P.; Solans, C.; Vauthier, C. Interactions of PLGA Nanoparticles with Blood Components: Protein Adsorption, Coagulation, Activation of the Complement System and Hemolysis Studies. Nanoscale 2015, 7, 6045-6058. [CrossRef]

37. Cao, W.; He, L.; Cao, W.; Huang, X.; Jia, K.; Dai, J. Recent Progress of Graphene Oxide as a Potential Vaccine Carrier and Adjuvant. Acta Biomater. 2020, 112, 14-28. [CrossRef]

38. Zhang, X.; Li, H.; Yi, C.; Chen, G.; Li, Y.; Zhou, Y.; Chen, G.; Li, Y.; He, Y.; Yu, D. Host Immune Response Triggered by Graphene Quantum-Dot-Mediated Photodynamic Therapy for Oral Squamous Cell Carcinoma. Int. J. Nanomed. 2020, 15, 9627-9638. [CrossRef]

39. Kędziora, A.; Wernecki, M.; Korzekwa, K.; Speruda, M.; Gerasymchuk, Y.; Łukowiak, A.; Bugla-Płoskońska, G. Consequences Of Long-Term Bacteria's Exposure To Silver Nanoformulations With Different PhysicoChemical Properties. Int. J. Nanomed. 2020, 15, 199-213. [CrossRef]

40. Allegra, E.; Titball, R.W.; Carter, J.; Champion, O.L. Galleria Mellonella Larvae Allow the Discrimination of Toxic and Non-Toxic Chemicals. Chemosphere 2018, 198, 469-472. [CrossRef]

41. Megaw, J.; Thompson, T.P.; Lafferty, R.A.; Gilmore, B.F. Galleria Mellonella as a Novel in Vivo Model for Assessment of the Toxicity of 1-Alkyl-3-Methylimidazolium Chloride Ionic Liquids. Chemosphere 2015, 139, 197-201. [CrossRef]

42. Maguire, R.; Duggan, O.; Kavanagh, K. Evaluation of Galleria Mellonella Larvae as an in Vivo Model for Assessing the Relative Toxicity of Food Preservative Agents. Cell Biol. Toxicol. 2016, 32, 209-216. [CrossRef]

43. Randall, C.P.; Gupta, A.; Jackson, N.; Busse, D.; O'Neill, A.J. Silver Resistance in Gram-Negative Bacteria: A Dissection of Endogenous and Exogenous Mechanisms. J. Antimicrob. Chemother. 2015, 70, 1037-1046. [CrossRef]

44. Lukowiak, A.; Gerasymchuk, Y.; Wedzynska, A.; Tahershamsi, L.; Tomala, R.; Strek, W.; Piatek, D.; Korona-Glowniak, I.; Speruda, M.; Kedziora, A.; et al. Light-Activated Zirconium(IV) Phthalocyanine Derivatives Linked to Graphite Oxide Flakes and Discussion on Their Antibacterial Activity. Appl. Sci. 2019, 9, 4447. [CrossRef]

45. Tahershamsi, L.; Gerasymchuk, Y.; Wedzynska, A.; Ptak, M.; Tretyakova, I.; Lukowiak, A. Synthesis, Spectroscopic Characterization and Photoactivity of $\mathrm{Zr}(\mathrm{IV})$ Phthalocyanines Functionalized with Aminobenzoic Acids and Their GO-Based Composites. C 2020, 6, 1. [CrossRef]

46. Human Serum P2918. Available online: https://www.sigmaaldrich.com/catalog/product/sigma/p2918 (accessed on 25 August 2019).

47. Skorek, K.; Raczkowska, A.; Dudek, B.; Miętka, K.; Guz-Regner, K.; Pawlak, A.; Klausa, E.; Bugla-Płoskońska, G.; Brzostek, K. Regulatory Protein OmpR Influences the Serum Resistance of Yersinia Enterocolitica O:9 by Modifying the Structure of the Outer Membrane. PLoS ONE 2013, 8, e79525. [CrossRef]

48. Moritz, S.; Bartz-Beielstein, T. imputeTS: Time Series Missing Value Imputation in R. R J. 2017, 9, 207-218. [CrossRef]

49. Sardá-Espinosa, A. Time-Series Clustering in R Using the Dtwclust Package. $R$ J. 2019, 11, 22-43. [CrossRef]

50. Demšar, J.; Curk, T.; Erjavec, A.; Gorup, Č.; Hočevar, T.; Milutinovič, M.; Možina, M.; Polajnar, M.; Toplak, M.; Starič, A.; et al. Orange: Data Mining Toolbox in Python. J. Mach. Learn. Res. 2013, 14, 2349-2353. 